\title{
The Potential Role of Nutraceuticals as an Adjuvant in Breast Cancer Patients to Prevent Hair Loss Induced by Endocrine Therapy
}

\author{
Giorgio Dell'Acqua ${ }^{1}$, Aleksander Richards ${ }^{1}\left(\mathbb{D}\right.$ and M. Julie Thornton ${ }^{2, *}$ (I) \\ 1 Nutrafol, New York, NY 10016, USA; giorgio@nutrafol.com (G.D.); aleksander@nutrafol.com (A.R.) \\ 2 Centre for Skin Sciences, University of Bradford, Bradford BD17 7DF, UK \\ * Correspondence: m.j.thornton@bradford.ac.uk
}

Received: 12 October 2020; Accepted: 16 November 2020; Published: 18 November 2020

\begin{abstract}
Nutraceuticals, natural dietary and botanical supplements offering health benefits, provide a basis for complementary and alternative medicine (CAM). Use of CAM by healthy individuals and patients with medical conditions is rapidly increasing. For the majority of breast cancer patients, treatment plans involve 5-10 yrs of endocrine therapy, but hair loss/thinning is a common side effect. Many women consider this significant, severely impacting on quality of life, even leading to non-compliance of therapy. Therefore, nutraceuticals that stimulate/maintain hair growth can be proposed. Although nutraceuticals are often available without prescription and taken at the discretion of patients, physicians can be reluctant to recommend them, even as adjuvants, since potential interactions with endocrine therapy have not been fully elucidated. It is, therefore, important to understand the modus operandi of ingredients to be confident that their use will not interfere/interact with therapy. The aim is to improve clinical/healthcare outcomes by combining specific nutraceuticals with conventional care whilst avoiding detrimental interactions. This review presents the current understanding of nutraceuticals beneficial to hair wellness and outcomes concerning efficacy/safety in breast cancer patients. We will focus on describing endocrine therapy and the role of estrogens in cancer and hair growth before evaluating the effects of natural ingredients on breast cancer and hair growth.
\end{abstract}

Keywords: breast cancer; estrogen receptor; hair follicle; aromatase inhibitors; tamoxifen; nutraceuticals; plant extract; endocrine therapy-induced hair loss

\section{Estrogens and Breast Cancer}

While estrogen has beneficial effects in many tissues, it also has a strong relationship with the initiation and development of endocrine-dependent cancers [1]. Breast cancer is the most common type of invasive cancer in women, accounting for over 500,000 deaths per year worldwide [2], and in the West, one in eight women will be diagnosed during her lifetime. Approximately $75-80 \%$ of all cases are estrogen receptor (ER)-positive [3]; therefore, increased estrogen exposure, e.g., early menarche, late menopause and long-term hormone-replacement therapy, is correlated with increased incidence [4]. This is further supported by data confirming that bilateral oophorectomy in women under 35 years of age reduces the lifetime risk by $75 \%$ [5]. Breast cancer is a heterogeneous disease, and transcriptomics have identified a number of molecular subtypes that are linked to diverse clinical outcomes. In addition to the ER, breast cancer cells can also express the progesterone receptor (PR) and/or HER2, an oncogene that belongs to human epidermal growth factor (EGF) receptor family. However, a proportion of breast cancers may be negative for all of these receptors (triple negative). The most common breast cancers are ER-positive and/or PR-positive and encompass two main molecular classifications: luminal A, which is 
HER2-negative and has low expression of Ki67, a marker of proliferation (35.6\%), and luminal B, which may be either HER2-positive (13.1\%) or -negative (22.5\%) but has a high expression of Ki67 and grows faster [6]. Triple negative/basal-like breast cancer (15.2\%) is more common in younger women, particularly those with $B R C A 1$ gene mutations, while the non-luminal HER2-positive subtype is ERand PR- negative and, although not as common, tends to grow faster than luminal subtypes (13.7\%) [6]. Interestingly, a recent study has also highlighted a protective role for parity and breastfeeding in breast cancer development, with parity associated with decreased risk of ER-positive breast cancer, while breastfeeding is inversely concomitant with hormone receptor-negative breast cancer [7].

Since 1996, it has been acknowledged that two distinct nuclear estrogen receptors (ER $\alpha$ and ER $\beta$ ) exist, binding $17 \beta$-estradiol with comparable affinity $[8,9]$. The distribution and expression of ER $\alpha$ and $E R \beta$ is highly variable. $E R \alpha$ is the predominant receptor in female reproductive tissues, including the uterus and mammary glands, and also the principal receptor in pituitary, skeletal muscle, adipose tissue and bone. In contrast, ER $\beta$ is the principal receptor in the ovary, prostate, lung, cardiovascular system and central nervous system [10]. Activation of ERs increases transcriptional activity via interactions with palindrome estrogen response elements (ERE) located in the promoter region of estrogen-regulated target genes [11] (Figure 1). The recruitment of coactivator complexes and histone acetyltransferases, which are cell specific, are also necessary [12], with ER $\alpha$ and ER $\beta$ often having opposing requirements [13]. ER $\alpha$ and ER $\beta$ bind to EREs as homodimers or heterodimers; the cellular ratio of $E R \alpha / E R \beta$ is thereby significant and impacts the response [14]. While classical estrogen signaling occurs via $E R \alpha / E R \beta$, many cells also express monomeric nuclear ERs that are trafficked from the cytoplasm following palmitoylation, via physical interaction with the caveolin-1 protein, transporting it to the caveolae rafts in the cell membrane $[15,16]$. Localization at the cell membrane works in partnership with cell membrane G-protein-coupled receptors (GPCRs), e.g., GPR30, to transmit rapid signals [17]. Although membrane-bound classical ERs lack the structural signaling domains of tyrosine kinase receptors, it appears that they can also transactivate the EGF or insulin-like growth factor 1 (IGF-1) receptors to stimulate kinase cascades [18].

While ER $\alpha$ is a key driver in ER-positive breast cancers, the molecular mechanisms of breast tumor initiation by estrogen are not fully understood. In normal mammary glands, ER $\alpha$ is tightly regulated via binding with $17 \beta$-estradiol, but this can become dysregulated, supporting tumor growth. It is thought that following conversion to quinone metabolites, estrogen binds directly to DNA, causing genotoxic effects and initiating mutations [19]. Activation of ER $\alpha$ by $17 \beta$-estradiol stimulates proliferation of these cells, which amass, forming a tumor [20]. As $75-80 \%$ of breast cancers are ER $\alpha$-positive, therapies to inhibit $E R \alpha$ signaling are central to treatment.

Currently, ER $\beta$ is not a diagnostic marker nor used in the treatment of breast cancer, and its role, if there is any, is unclear, although a number of studies suggest that it is an anti-oncogene [21]. In vitro studies indicate a role for $E R \beta$ in the inhibition of proliferation, migration and invasiveness of breast cancer cells [22,23]. Dysregulation of autophagy, which plays a key role in the maintenance of cellular homeostasis, has been implicated in many cancers. Recently, it has been suggested that an important regulatory role of ER $\beta$ in breast cancer is to induce autophagy [21,24]. Whether ER $\beta$ has a protective role in breast cancer is currently unknown, but understanding its mechanism of action may identify it as a potential target for new breast cancer treatments. 


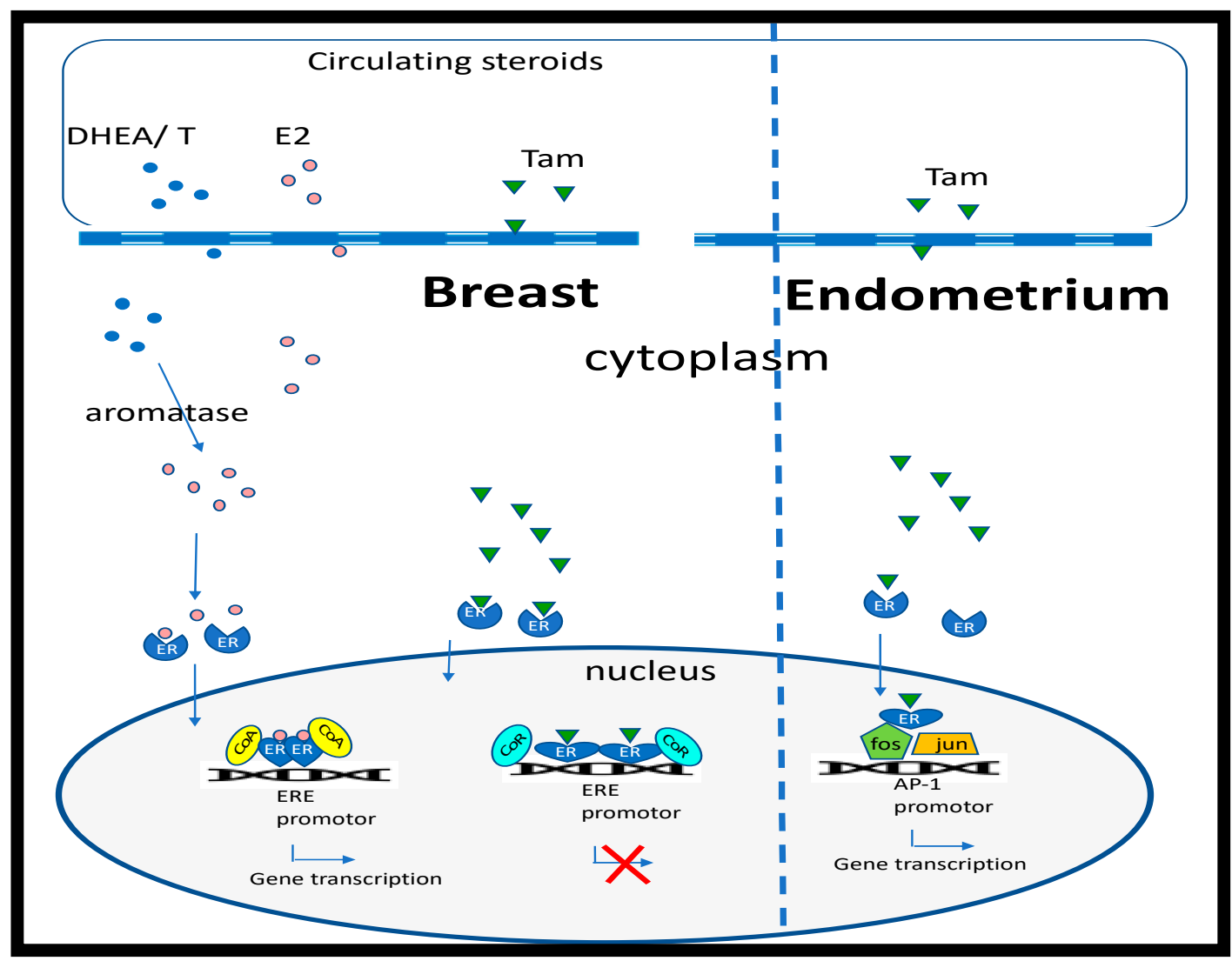

Figure 1. Regulation of estrogen-response genes by $17 \beta$-estradiol and tamoxifen. Estradiol (E2) (pink circles) passes through the cell membrane and binds to the estrogen receptor (ER), inducing a conformational change in shape and nuclear translocation, where it interacts with specific estrogen response elements (ERE) that regulate estrogen responsive genes, after recruiting cell-specific cofactors (CoA). E2 can be metabolized by aromatase from androgen precursors (blue circles; dehydroepiandrosterone (DHEA) or testosterone (T)). In breast cells, binding of tamoxifen (Tam) to ERs results in a conformational change that recruits corepressors (CoR) of gene transcription. However, in the endometrium, tamoxifen binding to the ER results in protein:protein interactions and activation of the activator protein 1 (AP-1) promotor.

Another important feature in the development of breast cancer is the peripheral biosynthesis of estrogen from adrenal precursors (Figure 2). Breast tissue expresses high levels of aromatase, the enzyme required for the terminal biosynthesis of androgens into estrogens [25,26]. Furthermore, aromatase levels can vary in heterogeneous cells populations, with the contribution of aromatase in normal breast changing in magnitude with the development of a tumor [27] and, hence, increasing the local bioavailability of estrogen. 


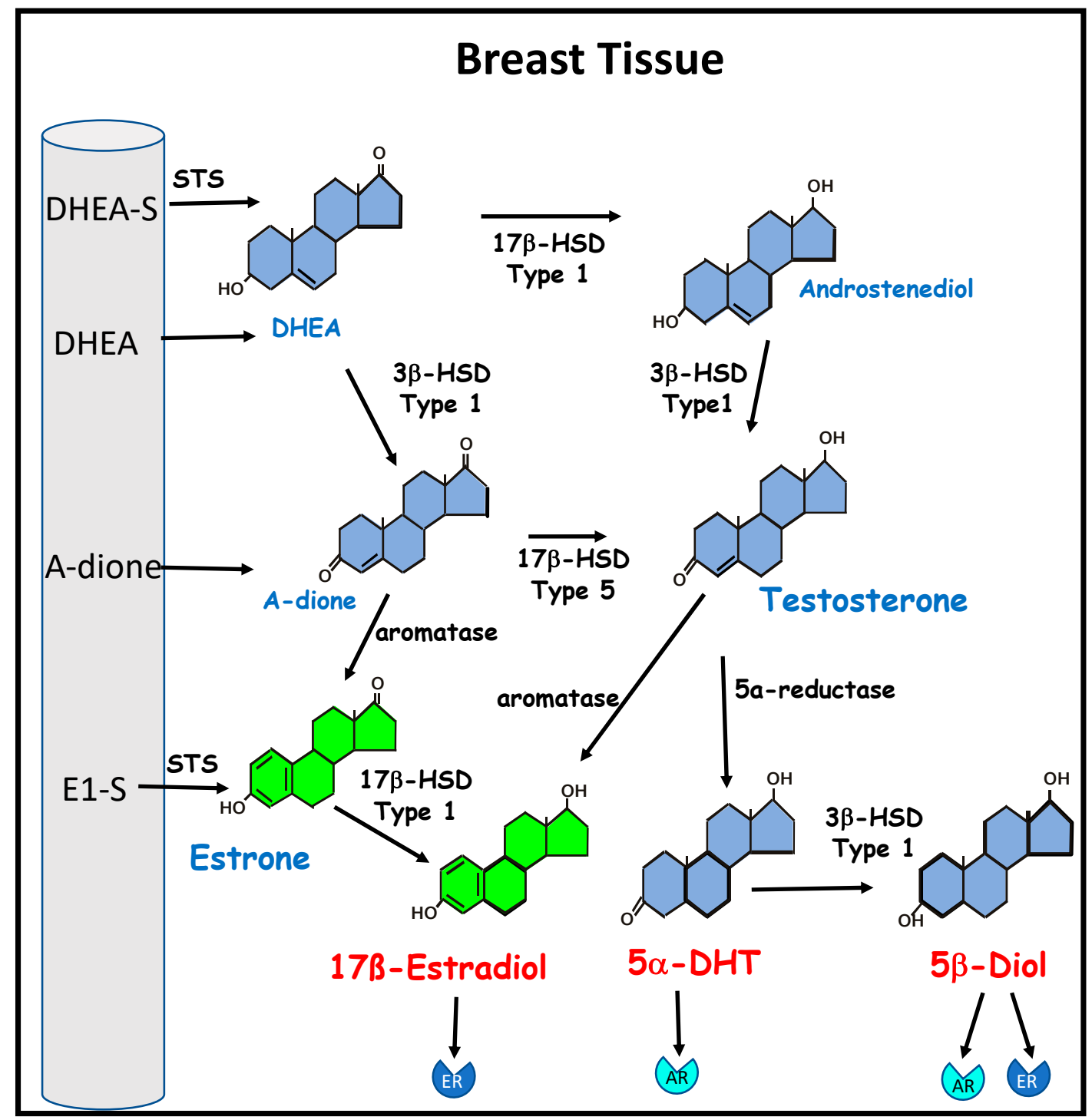

Figure 2. The biosynthesis of estrogen from inactive circulating precursors in breast cancer. Bioactive estrogen can be synthesized by breast cancer cells and breast stromal tissue from circulating precursor steroids. These include the adrenal androgens dehydroepiandrosterone (DHEA) and androstenedione (A-dione); dehydroepiandrosterone sulphate (DHEA-S), the major circulating androgen, and estrone sulphate (E1-S), the major circulating estrogen in postmenopausal women, which can be converted to DHEA and estrone (E1), respectively, by steroid sulfatase (STS). DHEA and androstenediol are metabolized by $3 \beta$ - hydroxysteroid dehydrogenase ( $3 \beta$-HSD) type 1 to the estrogen precursors A-dione and testosterone. Testosterone can be metabolized by $5 \alpha$-reductase to the potent androgen $5 \alpha$-dihydrotestosterone ( $5 \alpha$-DHT), which has a high affinity for the androgen receptor (AR). Type $13 \beta$-HSD can convert $5 \alpha$-DHT to $5 \alpha$-androstane- $3 \beta, 17 \beta$-diol ( $5 \beta$-diol), which is an agonist of both the AR and the estrogen receptor (ER). Aromatase is required for the conversion of testosterone to $17 \beta$-estradiol and conversion of A-dione to E1, which can be further metabolized by $17 \beta$ hydroxysteroid dehydrogenase (17 $\beta$-HSD) type 1 to $17 \beta$-estradiol, which has a high affinity for ER.

\section{Breast Cancer Treatment}

Until the 1970s, when new therapies began to emerge, aggressive mastectomy with removal of all glandular tissue including axillary lymph glands was the only approach available. In 1971, the non-steroidal triphenylethylene tamoxifen (brand name Nolvadex) went into a clinical trial and still remains the gold standard for the treatment of primary ER-positive breast cancer today [28,29]. 
While HER2-positive breast cancers grow faster than luminal cancers and can have a worse prognosis, patients with early-stage breast cancer are often treated successfully with trastuzumab (Herceptin), a HER2-specific monoclonal antibody targeted at the HER2 protein [30]. All breast cancer treatment encompasses radiotherapy, plus chemotherapy depending on the type of tumor, and while early-stage triple-negative breast cancer responds to chemotherapy, an optimal course of therapy still remains undefined [31].

Despite the success of tamoxifen as an ER $\alpha$ antagonist in breast cancer treatment, only $70 \%$ of $\mathrm{ER} \alpha$-positive patients respond, with $30 \%$ becoming resistant to endocrine therapy [32]. In addition, tamoxifen is correlated with an increased risk of endometrial cancer since it acts as an ER $\alpha$ agonist in the endometrium [33]. These observations that anti-estrogens can have mixed agonist/antagonist properties led to their redefinition as selective estrogen receptor modulators, or SERMs [34]. SERMs display mixed properties due to their individual cell-specific activity (Figure 1). While tamoxifen remains the gold standard for treatment of ER $\alpha$-positive breast cancer in premenopausal women, aromatase inhibitors, including anastrozole, letrozole and exemestane, that suppress estrogen biosynthesis are the preferred option following menopause and in tamoxifen-resistant patients [35]. However, while tamoxifen only blocks $E R \alpha$ receptors in tissues where it acts as an antagonist (e.g., breast), due to tissue selectivity, it may have beneficial effects in other tissues where it acts as an agonist, e.g., bone. In contrast, aromatase inhibitors will block all estrogen action.

\section{Estrogen and Hair Growth}

The human hair follicle has an exceptional capacity for regeneration, cycling numerous times throughout adult life (Figure 3), and each cycle can result in a change in the hair fiber produced, e.g., in size or color [36]. When the growth phase (anagen) ends, the lower portion of the hair follicle undergoes programmed apoptosis and regression (catagen), followed by a resting, maintenance stage (telogen) before the existing hair is shed (exogen) and a new cycle commences. The time in each phase can alter over a lifetime, although on the scalp, approximately $80 \%$ of hair follicles are in anagen, which can last from 2 to 8 years [37]. During pregnancy, an increased number of hair follicles are maintained in anagen, resulting in denser hair. Postpartum, these additional anagen follicles enter telogen at the same time, causing temporary hair thinning [38]. Although estrogen levels fluctuate on a monthly basis and are high during pregnancy, menopause leads to a permanent state of hypoestrogenism due to programmed dissolution of ovarian estrogen biosynthesis [39]. Low menopausal estrogen levels correlate with a gradual diffuse thinning of scalp hair in women, along with changes in growth, diameter and pigmentation [40]. Notwithstanding, the link between hypoestrogenism and female pattern hair loss (FPHL) is still not well understood, although genome-wide association studies comparing aromatase (CYP19A1) and ER $\beta$ (ESR2) in almost 500 women affected with FPHL against 500 controls, demonstrated a nominal significant association with three single-nucleotide polymorphisms (SNPs) of each of the two genes [41,42].

A comparison of $E R \alpha$ and $E R \beta$ expression in human scalp has verified that $E R \beta$ is the principal ER in the hair follicle [43]. Cultured mesenchymal hair follicle cells (dermal papilla and dermal sheath), as well as interfollicular dermal fibroblasts, also predominately express ER $\beta$ [44]. Although menopause terminates ovarian function, peripheral estrogen biosynthesis from circulating adrenal androgens provides a source of estrogen post-menopause [45]. Similar to breast tissue, human hair follicles express the aromatase enzyme allowing them to regulate their own bioavailability of estrogens [46,47]. However, aromatase activity in human scalp varies with gender and anatomical region [48]. A recent study of women with FPHL has shown that they have a significantly lower expression of aromatase in their hair follicles, which will minimize estrogen bioavailability [49]. 


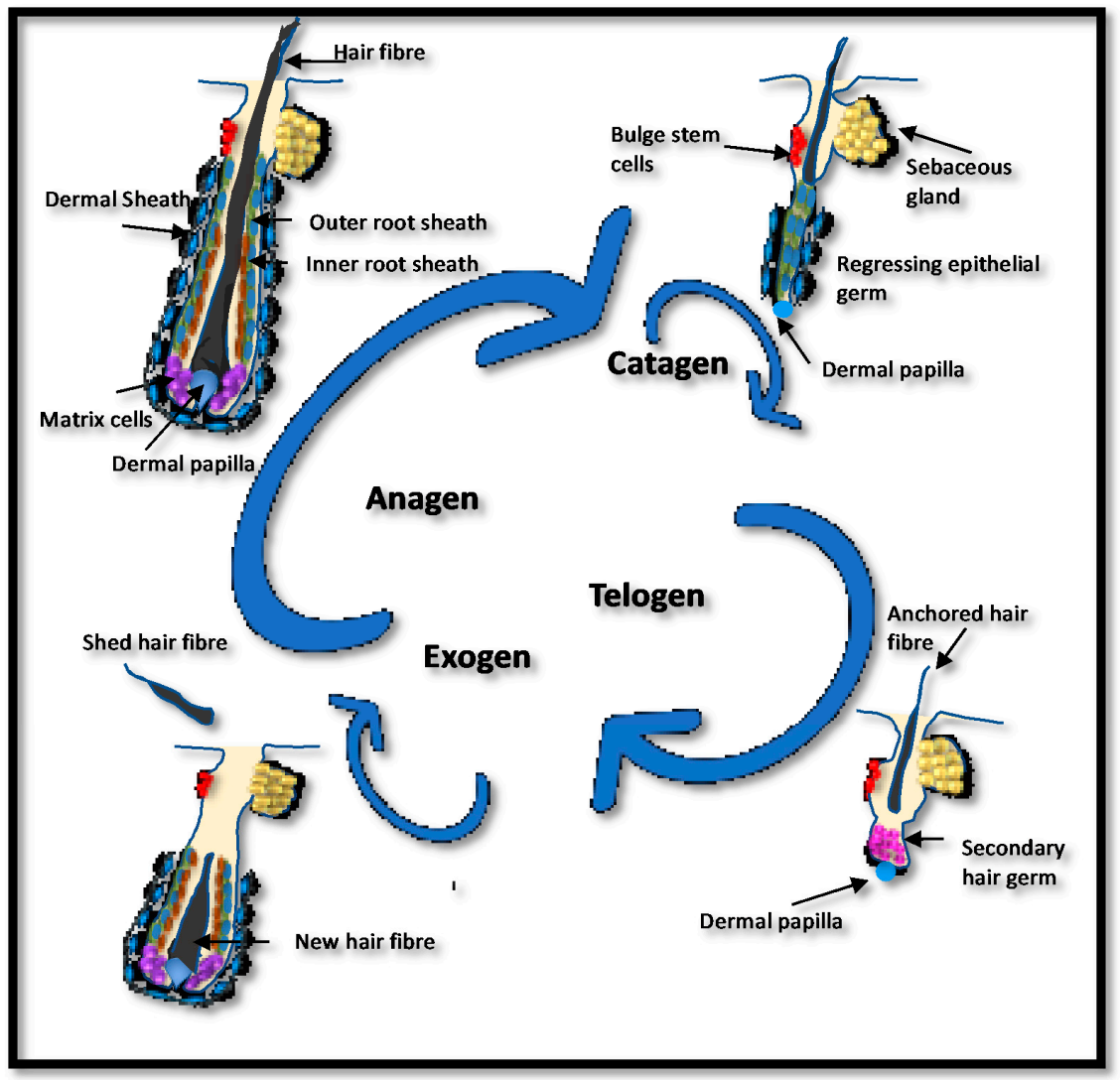

Figure 3. The human hair cycle. Hair follicles cycle throughout life with a growing phase (anagen) followed by regression (catagen) and maintenance (telogen). The hair fiber is shed during exogen, which usually coincides with the start of a new cycle. Bulb matrix cells proliferate and differentiate to produce the new follicle and hair fiber. In their center, the dermal papilla directs the type of hair produced. During catagen, the lower hair follicle regresses before entering telogen, where the hair fiber is firmly anchored but no further growth occurs. The length of anagen and telogen vary and will determine overall hair growth. If hair is shed before the initiation of a new anagen, the hair follicle may sit empty, a stage known as kenogen. Shortened anagen, lengthened telogen and increased exogen/kenogen can result in hair thinning. The number of hair follicles in kenogen is increased in women with female pattern hair loss (FPHL) [50].

\section{Endocrine Therapy-Induced Hair Loss (ETIHL)}

While the selective action of tamoxifen has beneficial effects on some estrogen-target tissues, e.g., bone, some women report scalp hair thinning as a side effect [51]. Likewise, data on aromatase inhibitors reported that up to $25 \%$ of the patients receiving treatment experienced hair loss or thinning [52]. Either blocking estrogen receptors with an antagonist, such as tamoxifen, or reducing estrogen bioavailability with aromatase inhibitors may inhibit the proliferation of scalp hair follicles [53] and induce them to enter the resting phase [54]. In a clinical study of 112 breast cancer patients on endocrine therapy, a patterned alopecia similar to androgenetic type (male pattern baldness) was confirmed by standardized clinical and trichoscopy images identifying the presence of vellus hairs and intermediateand thick-diameter terminal hair shafts [55]. In 75 patients (67\%) hair thinning was attributed to treatment with aromatase inhibitors and in 37 patients (33\%) to treatment with tamoxifen. In $76 \%$ of cases, a more prominent recession of the frontotemporal area was observed. Treatment with topical minoxidil improved hair loss in 37 patients $(80 \%)$, as documented through standardized clinical photographs of the scalp obtained at baseline and then after 3 or 6 months [55]. In a larger study of a cohort, 19,430 patients with endocrine-related cancers in 35 clinical trials were analyzed for effects on hair growth. Of these, 13,415 patients had received endocrine treatment, while 6015 patients served as 
controls. The incidence of all grades of alopecia ranged from $0 \%$ to $25 \%$, with an overall incidence of 4.4\% (95\% confidence interval: 3.3-5.9\%). The highest incidence was observed in patients treated with tamoxifen in a phase II trial (25.4\%) [52]. Because ETIHL negatively affects sociocultural status and quality of life, it is a major problem and remains a therapeutic challenge in patients with breast cancer. Supplementation with vitamins (D, E, C, folic acid) and/or omega-3 fatty acids has been a popular adjuvant therapy, often associated in combination with minoxidil $[35,56]$.

\section{Estrogens as Antioxidants}

Although the role of intracellular ERs in estrogen signaling is well established, other ER-independent mechanisms have also been described [5]. Estrogen has been shown to have a protective effect against oxidative stress, which is independent of ER $\alpha$ and ER $\beta$ [57]. These antioxidant properties appear to be due to the structural properties of estrogen, in particular the phenolic A-ring that diminishes any reactive oxygen species (ROS) via a cyclic phenol-quinol mechanism [58]. The phenolic A ring structure of $17 \beta$-estradiol (Figure 4) can act as an antioxidant, providing antioxidant/redox cycling activity, which limits the release of ROS from damaged mitochondria, thereby protecting against cell damage [59]. These specific antioxidant properties can suppress oxidative stress induced by hydrogen peroxide, superoxide anions and other pro-oxidants by mechanism(s) independent of estrogen binding to the ERs [60]. Estrogen can protect against skin photoaging and improve the rate and quality of wound healing; however, these responses appear to be ER-dependent since both ER $\alpha$ and ER $\beta$ are expressed in human skin, including epidermal keratinocytes, dermal fibroblasts and hair follicle cells $[43,44,46]$. Furthermore, $17 \beta$-estradiol has been shown to exert a cytoprotective effect on cultured dermal fibroblasts derived from a patient with Friedreich's ataxia, which are extremely sensitive to free radical damage and oxidative stress. Since these skin fibroblasts also express ERs, they were cultured in the presence of ICI 182,780, an antagonist of both ER $\alpha$ and ER $\beta$ and G15 the antagonist of the GPR30 cell membrane estrogen receptor, demonstrating that the cytoprotective effects of $17 \beta$-estradiol were independent of the ERs [57,59]. They concluded that these cytoprotective effects were dependent on antioxidant properties endowed by the phenolic structure of $17 \beta$-estradiol, since other phenolic compounds tested were protective, whereas all nonphenolic compounds were ineffective at reducing the levels of ROS.

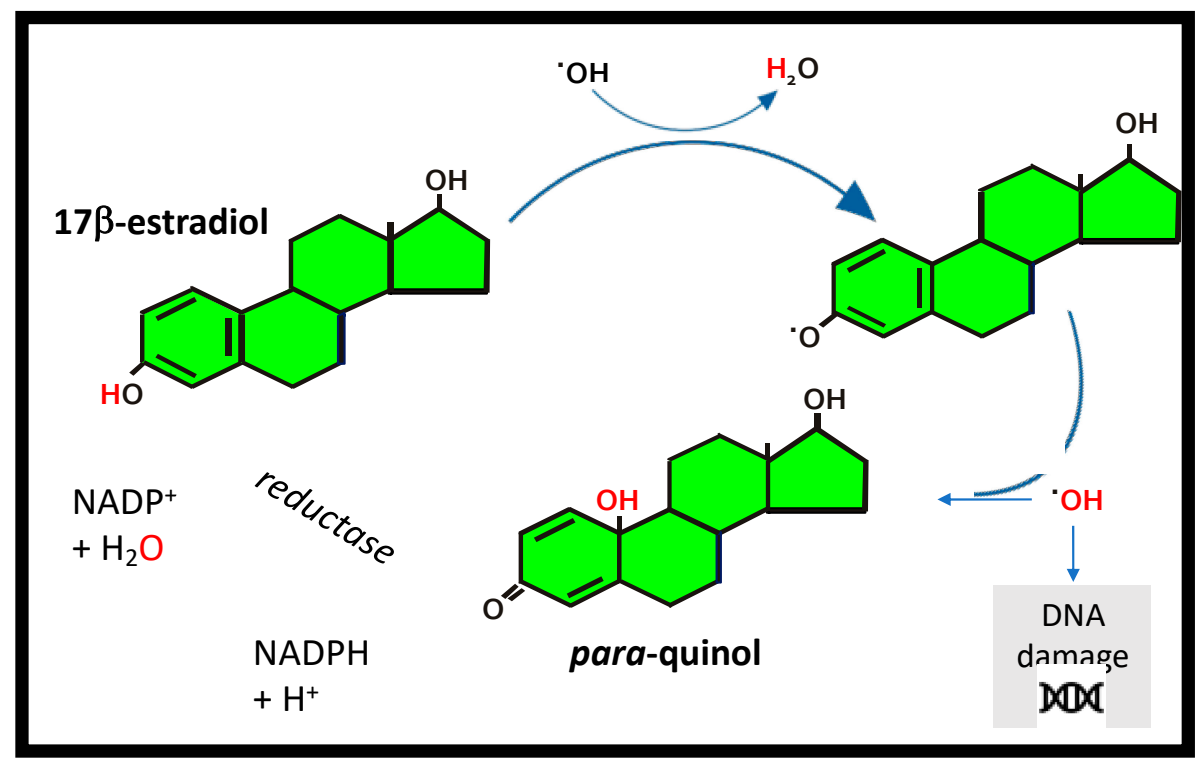

Figure 4. $17 \beta$-estradiol as an antioxidant. The antioxidant cycle for $17 \beta$-estradiol by transfer of a $\mathrm{H}$-atom to a free radical $\left({ }^{\bullet} \mathrm{OH}\right)$, to form a phenoxyl radical that scavenges ${ }^{\bullet} \mathrm{OH}$ forming a para-quinol which undergoes enzymatic reduction in the presence of the cofactor nicotinamide adenine dinucleotide phosphate (NADPH) to convert back to $17 \beta$-estradiol. 


\section{Natural Ingredients and Their Effect on Breast Cancer and Hair Growth}

Many plants can synthesize compounds that are structurally similar to $17 \beta$-estradiol. The crucial similarity that these phytoestrogens share with $17 \beta$-estradiol is their phenolic hydroxyl A ring, which plays a key role in docking to the ligand binding domains of $\operatorname{ER} \alpha$ and $E R \beta$, enabling them to mimic the effects of $17 \beta$-estradiol [61]. These hydrophobic polyphenolic compounds are considered to be naturally occurring SERMs since they can interact with both ER $\alpha$ and ER $\beta$ in either an agonistic or antagonistic manner [62]. Such nutraceuticals include resveratrol, a naturally occurring polyphenolic stilbene found in the skin of grapes, blueberries, raspberries and mulberries and in red wine [63]; tocotrienols, naturally occurring compounds found in plant seeds, such as rice bran, oil palm and annatto and belonging to the vitamin E family [64]; and brown seaweeds (kelp), which in addition to acting as an antagonist of $\mathrm{ER} \alpha$, are also inhibitors of aromatase, suggesting a protective role in the initiation and progression of estrogen-dependent cancers [65]. In contrast, saw palmetto (Serona repens) extract derived from the berries of the American dwarf tree is a competitive, nonselective inhibitor of both forms of $5 \alpha$-reductase. It blocks nuclear uptake of $5 \alpha$-DHT in target cells and decreases $5 \alpha$-DHT binding to androgen receptors by approximately $50 \%$. Additionally, the extract increases $3 \alpha$-hydroxysteroid-dehydrogenase activity, increasing the conversion of $5 \alpha$-DHT to its weaker metabolite, androstanediol [66].

Many nutraceuticals also exhibit strong anti-inflammatory and antioxidant properties. For example, astaxanthin, a carotenoid produced when the freshwater algae Haematococcus pluvialis is subjected to stress, it is a powerful antioxidant superior to other carotenoids [67]. It preserves the integrity of the cell membrane via its insertion into the lipid bilayer, thereby protecting the redox state and integrity of the mitochondria by decreasing ROS and stimulating the production of antioxidants, such as superoxide dismutase (SOD), catalase and glutathione (GSH) [68,69]. Maca (Lepidium meyenii) extract is derived from the roots of the plant found in the Andean region of South America and contains high levels of flavonolignans and glucosinolates that have been reported to have anti-proliferative activity against several cancers, including breast cancer [70,71]. The health benefits of curcumin, the main secondary metabolites of turmeric (Curcuma longa) extract, which is derived from the roots of the plant mainly grown in India, have been linked to its anti-inflammatory and antioxidant action [72]. Horsetail (Equisetum arvense) another plant extract used in traditional medicine also exhibits strong anti-inflammatory and antioxidant properties [73]. A plant extract which is particularly rich in steroid withanolides that exhibits anti-inflammatory properties is ashwagandha (Withania somnifera) [74]. It has well-documented anti-cancer properties and has been shown to suppress ER- $\alpha$ protein level by about $90 \%$ in breast cancer cells, while increasing the expression of ER- $\beta$ protein by about $20-30 \%$ [75]. Nutritional factors appear to play a role in persistent increased hair shedding-e.g., serum ferritin concentrations factor in female hair loss [76] and supplementation with omegas 3 and 6 can reduce hair loss by improving hair density and reducing the percentage of telogen hair follicles [77]. Recently, it has been demonstrated that nutraceuticals containing Annurca apple polyphenols (Malus pumila Miller cv. Annurca) can promote human hair growth, increasing hair density, weight and keratin content both in vitro and in vivo [78]. A summary of the protective and inhibitory effects of different nutraceuticals on breast cancer and their potential effect on improving hair growth is given in Table 1. 
Table 1. A summary of the estrogenic and antioxidant properties of nutraceuticals that provide a basis for complementary and alternative medicine in both breast cancer and hair growth. Their protective and inhibitory effects on breast cancer are summarized in addition to a potential role for the improvement of hair growth.

\begin{tabular}{|c|c|c|c|c|}
\hline NUTRACEUTICAL & PROPERTIES & BREAST CANCER & HAIR GROWTH & $\begin{array}{l}\text { POTENTIAL } \\
\text { ADJUVANT }\end{array}$ \\
\hline Resveratrol & $\begin{array}{l}\text { Naturally occurring polyphenolic stilbene } \\
\text { found in, blueberries, raspberries, mulberries, } \\
\text { grapes and red wine. Can signal via ER } \alpha \text { and } \\
\text { ER } \beta \text {. An effective antioxidant with strong } \\
\text { anti-inflammatory properties. }\end{array}$ & $\begin{array}{l}\text { Inhibits estrogen-induced breast } \\
\text { carcinogenesis via induction of } \\
\text { NRF2-mediated protective pathways [79]. } \\
\text { Induction of apoptosis in ER +ve MCF-7 cells } \\
\text { is via inhibition of the ER } \alpha \text {-dependent PI3K } \\
\text { pathway [80]. Resveratrol analogues } \\
\text { combined with tamoxifen have a synergistic } \\
\text { effect on inhibiting proliferation of ER +ve } \\
\text { and ER-ve breast cancer cells [81]. }\end{array}$ & $\begin{array}{l}\text { Using the sensitive probe DCFH-DA, it was shown } \\
\text { to significantly reduce oxygen peroxide-induced } \\
\text { oxidative stress generated in hair follicles and hair } \\
\text { matrix cells [82]. Furthermore, a clinical study of } 79 \\
\text { women suffering from hair loss treated with a topical } \\
\text { combination of pyridine-2, 4-dicarboxylic acid } \\
\text { diethyl ester and resveratrol reported significantly } \\
\text { increased hair density after } 1.5 \text { months [82]. }\end{array}$ & $\begin{array}{l}\text { Anti-carcinogenic. } \\
\text { Synergizes with tamoxifen. } \\
\text { Anti-inflammatory. } \\
\text { Antioxidant. } \\
\text { Potential to improve hair density in } \\
\text { women and reduce oxidative stress. }\end{array}$ \\
\hline Tocotrienols & $\begin{array}{l}\text { Hydrophobic phenolic antioxidants with } \\
\text { structural features allow binding to ER } \alpha \text { and } \\
\text { ER } \beta \text {. Found in plant seeds, e.g., rice bran, oil } \\
\text { palm and annatto; belong to the vitamin E } \\
\text { family [64]. }\end{array}$ & $\begin{array}{l}\text { Exhibit high affinity for ER } \beta \text { and promote } \\
\text { nuclear translocation, modulating cell } \\
\text { morphology, caspase-3 activation, DNA } \\
\text { fragmentation and apoptosis }[83,84] \text {. Binding } \\
\text { to ER } \beta \text { induces apoptosis in breast cancer } \\
\text { cells }[84,85] \text {. Can synergize with tamoxifen } \\
\text { to inhibit proliferation [86] with a clinical } \\
\text { trial suggesting breast cancer survival may } \\
\text { be extended by combining tocotrienol with } \\
\text { tamoxifen therapy [87]. Proliferation of } \\
\text { ER-negative breast cancer cell line can also be } \\
\text { inhibited by } \alpha-, \gamma \text { - and } \delta \text {-tocotrienols [86,88]. }\end{array}$ & $\begin{array}{l}\text { Induce murine hair follicle development and } \\
\text { stimulate anagen hair cycling by suppressing } \\
\text { epidermal E-cadherin followed by a } 4 \text {-fold induction } \\
\text { of } \beta \text {-catenin and its nuclear translocation [89]. } \\
\text { In an 8-month treatment of } 38 \text { patients with hair loss, } \\
\text { increased hair counts in } 34.5 \% \text { [90]; thought to be } \\
\text { due to inhibition of lipid peroxidation and reduction } \\
\text { in oxidative stress in the hair follicle. }\end{array}$ & $\begin{array}{l}\text { ER } \beta \text { agonist. } \\
\text { Anti-carcinogenic. } \\
\text { Synergizes with tamoxifen. } \\
\text { Antioxidant. } \\
\text { Potential to improve hair cycling } \\
\text { and reduce oxidative stress. }\end{array}$ \\
\hline $\begin{array}{l}\text { Saw palmetto } \\
\text { (Serenoa repens) }\end{array}$ & $\begin{array}{l}\text { American dwarf tree berries. Competitive, } \\
5 \alpha \text { reductase }(1 \text { and } 2) \text { inhibitor. Multiple } \\
\text { sites of action-different pharmacodynamic } \\
\text { profile to finasteride [66]. Increases } \\
3 \alpha \text {-hydroxysteroid-dehydrogenase activity, } \\
\text { converting } 5 \alpha \text {-DHT to a weaker metabolite, } \\
\text { androstanediol [66]. }\end{array}$ & $\begin{array}{l}\text { Induces dose-dependent inhibition of ER }+ \\
\text { ve/-ve breast cancer cell line proliferation. } \\
\text { Inhibition } 2.5 x \text { greater }(p<0.01) \text { in MCF-7 } \\
\text { cells (ER +ve) than MDA MB231 cells (ER } \\
\text {-ve) [91]. The anti-proliferative effect was } \\
\text { triggered by the induction of apoptosis. Has } \\
\text { anti-estrogenic activity in prostate tissue of } \\
\text { men with BPH [92]. Furthermore, decreases } \\
5 \alpha \text {-DHT and estradiol plasma levels in men } \\
\text { [93]. }\end{array}$ & $\begin{array}{l}\text { Most studies have been conducted on men with } \\
\text { androgenetic alopecia. Daily treatment with } 200 \mathrm{mg} \\
\text { in } 26 \text { men with androgenetic alopecia saw } \\
\text { improvement in } 60 \% \text { compared to } 11 \% \text { with placebo } \\
\text { [94]. A daily oral supplement of } 320 \mathrm{mg} \text { compared } \\
\text { to } 1 \mathrm{mg} \text { finasteride in } 100 \text { men saw more growth on } \\
\text { frontal and vertex scalp in } 68 \% \text { of the finasteride } \\
\text { cohort, while } 38 \% \text { of the saw palmetto group had } \\
\text { increased hair growth on the vertex [95]. A topical } \\
\text { application saw increased terminal hair counts after } \\
12 \text { and } 24 \text { weeks [96]. }\end{array}$ & $\begin{array}{l}5 \alpha \text {-reductase inhibitor. } \\
\text { Anti-carcinogenic. } \\
\text { Potential to improve terminal hair } \\
\text { counts, particularly on vertex. }\end{array}$ \\
\hline
\end{tabular}


Table 1. Cont

\begin{tabular}{|c|c|c|c|c|}
\hline NUTRACEUTICAL & PROPERTIES & BREAST CANCER & HAIR GROWTH & $\begin{array}{l}\text { POTENTIAL } \\
\text { ADJUVANT }\end{array}$ \\
\hline $\begin{array}{c}\text { Maca } \\
\text { (Lepidium meyenii) }\end{array}$ & $\begin{array}{l}\text { Plant roots (Andes) contain high levels of } \\
\text { flavonolignans and glucosinolates. } \\
\text { Protective against inflammation, increases } \\
\text { antioxidants and has hormonal balancing } \\
\text { properties. Supports the antioxidant system } \\
\text { by activating SOD and GSH [97]. }\end{array}$ & $\begin{array}{l}\text { Has anti-proliferative activity against cancer, } \\
\text { including breast cancer [63,64]. In rats with } \\
\text { BPH), oral supplementation of a butanol } \\
\text { fraction of red maca reduces prostate size by } \\
\text { restoring ER } \beta \text { expression without changing } \\
\text { ARs and ER } \alpha \text { expression [98]. In } \\
\text { postmenopausal women, after } 2 \text { months, } \\
\text { Maca stimulated estradiol and suppressed } \\
\text { cortisol [99]. It modulates estrogen levels by } \\
\text { targeting only ER } \beta \text { and/or re-establishing } \\
\text { hormonal homeostasis through the } \\
\text { hypothalamus-pituitary-ovarian axis [99]. }\end{array}$ & $\begin{array}{l}\text { IL-6 has been implicated in forms of hair loss such as } \\
\text { AA [100]. Blood analysis of individuals consuming } \\
\text { Maca has shown a reduced level of IL-6 [101], } \\
\text { suggesting potential application for treatment of AA. } \\
\text { Maca has the ability to support the antioxidant } \\
\text { defense system by activating SOD and GSH [97], } \\
\text { which are powerful antioxidants that lower levels of } \\
\text { oxidative stress in forms of hair loss such as AGA } \\
\text { [102]. }\end{array}$ & $\begin{array}{l}\text { Anti-carcinogenic. } \\
\text { Anti-inflammatory. } \\
\text { Antioxidant. } \\
\text { Potential to reduce oxidative stress } \\
\text { in the hair follicle and improve hai } \\
\text { growth. }\end{array}$ \\
\hline Curcumin & $\begin{array}{l}\text { Curcumin is the main metabolite in turmeric } \\
\text { (Curcuma longa) root, with anti-inflammatory } \\
\text { and antioxidant properties [72]. It } \\
\text { down-regulates inducible nitric oxide and } \\
\text { cyclooxygenase-2; inhibits nuclear factor-kB } \\
\text { signaling, decreasing pro-inflammatory } \\
\text { cytokines, e.g., TNF- } \alpha \text { and IL-1, which are } \\
\text { implicated in hair loss [103]. It is recognized } \\
\text { as a strong anti-cancer agent, including } \\
\text { breast cancer, in traditional medicine [104]. }\end{array}$ & $\begin{array}{l}\text { Inhibits proliferation of T-47D breast cancer } \\
\text { cells in a dose-dependent manner by } \\
\text { downregulating ER } \alpha[105,106] \text {. It has } \\
\text { antioxidant and anti-inflammatory action } \\
\text { and can induce cell cycle arrest in breast } \\
\text { cancer cells [107]. Studies on other } \\
\text { estrogen-sensitive cancer cell lines, have } \\
\text { demonstrated a capacity to counteract the } \\
\text { proliferative effect of estradiol [108] as well } \\
\text { as the synthesis of estradiol [109]. }\end{array}$ & $\begin{array}{l}\text { Encapsulating curcumin in liposomes enhances } \\
\text { penetration in porcine hair follicles by } 70 \% \text { [110]. } \\
\text { Similarly, a cyclodextrin complex enhances } \\
\text { curcumin follicle penetration [111]. In vitro it } \\
\text { blocked expression of genes that inhibit hair growth, } \\
\text { e.g., PAK1 and TGF- } \beta 1 \text { [112,113]. Topical } \\
\text { application (5\%) or in combination with } 5 \% \\
\text { minoxidil was assessed in } 87 \text { men with androgenetic } \\
\text { alopecia for } 6 \text { months, demonstrating that while } \\
\text { curcumin alone did not stimulate hair growth, a } \\
\text { combination with minoxidil showed a significant } \\
\text { improvement, suggesting they may act in a } \\
\text { synergistic manner [114]. }\end{array}$ & $\begin{array}{l}\text { Anti-carcinogenic. } \\
\text { Anti-inflammatory. } \\
\text { Antioxidant. } \\
\text { Synergizes with minoxidil with the } \\
\text { potential to improve hair growth. }\end{array}$ \\
\hline
\end{tabular}


Table 1. Cont

\begin{tabular}{|c|c|c|c|c|}
\hline NUTRACEUTICAL & PROPERTIES & BREAST CANCER & HAIR GROWTH & $\begin{array}{l}\text { POTENTIAL } \\
\text { ADJUVANT }\end{array}$ \\
\hline $\begin{array}{c}\text { Ashwagandha } \\
\text { (Withania somnifera) }\end{array}$ & $\begin{array}{l}\text { Derived from the root and leaf of the plant, } \\
\text { which is particularly rich in withanolides, } \\
\text { which are the main active ingredients and } \\
\text { have anti-inflammatory and adaptogenic } \\
\text { properties [74]. } \\
\text { Ashwagandha and its actives have been } \\
\text { proposed as anti-cancer agents that are able } \\
\text { to modulate apoptotic, proliferative and } \\
\text { metastatic markers in cancer }[115,116] .\end{array}$ & $\begin{array}{l}\text { In breast cancer, it demonstrates } \\
\text { chemo-preventive activity in female rats } \\
\text { following administration of the mammary } \\
\text { carcinogen methylnitrosourea by } \\
\text { significantly reducing the rate of cell } \\
\text { proliferation in mammary tumors [117]. In } \\
\text { MCF-7 cells, withaferin, the main active } \\
\text { ingredient, suppressed ER- } \alpha \text { protein by } 90 \% \text {, } \\
\text { while expression of ER- } \beta \text { protein increased } \\
\text { by 20-30\% [75]. Withaferin-mediated } \\
\text { down-regulation of ER- } \alpha \text { protein expression } \\
\text { correlated with a decrease in its nuclear level, } \\
\text { suppression of its mRNA level, and } \\
\text { inhibition of estrogen-dependent activation } \\
\text { of ERE2e1b-luciferase reporter gene [75]. In } \\
\text { another study, it was shown that } \\
\text { ashwagandha inhibited proliferation and } \\
\text { induced apoptosis in the MCF-7 breast } \\
\text { cancer cell line by down-regulating ER } \alpha \\
\text { protein levels via proteasome-dependent } \\
\text { ER } \alpha \text { degradation [118]. Furthermore, } \\
\text { withaferin alters the mitochondria dynamic } \\
\text { resulting in apoptosis in breast cancer cells } \\
\text { [119] and impairs cancer autophagy resulting } \\
\text { in proteotoxicity and death [120]. Since } \\
\text { withaferin has shown activity in triple } \\
\text { negative breast cancer cells MDA-MB-231, by } \\
\text { blocking their invasiveness and associated } \\
\text { markers, the active has been suggested for } \\
\text { further (pre)clinical development to defeat } \\
\text { aggressive metastatic breast cancer [121]. }\end{array}$ & $\begin{array}{l}\text { Ashwagandha extract has anti-stress and } \\
\text { anti-anxiety properties [122]. Being a powerful } \\
\text { adaptogen, the extract has the ability to keep cortisol } \\
\text { levels at a healthy homeostatic level while } \\
\text { improving one's resistance to stress [123,124]. } \\
\text { Chronic stress activates the HPA axis by increasing } \\
\text { cortisol levels, which, in turn, inhibits the HPT axis } \\
\text { and reduces serum T3 and T4 levels [125]. } \\
\text { Endocrine disorders, such as hypothyroidism, can } \\
\text { cause hair loss [126]. Treatment with ashwagandha } \\
\text { lowers serum cortisol levels by downregulation of } \\
\text { the HPA axis, which, in turn, upregulates the HPT } \\
\text { axis to normalize the thyroid hormone level [127]. } \\
\text { Thyroid hormones, such as T3, are integral to hair } \\
\text { growth and wellness [128]. High-concentration, } \\
\text { full-spectrum ashwagandha root extract can } \\
\text { improve resistance towards stress and anxiety [129]. } \\
\text { Anxiety can contribute to hair loss as evidenced by a } \\
\text { study finding a high prevalence of anxiety } \\
\text { symptoms in patients with alopecia areata [130]. } \\
\text { Stress has been associated with hair loss, such as in } \\
\text { the case of telogen effluvium, characterized by a } \\
\text { non-scarring, non-inflammatory alopecia of } \\
\text { relatively sudden onset caused by physiologic or } \\
\text { emotional stress [131]. Use of ashwagandha would } \\
\text { then reduce the impact of stress on hair loss. }\end{array}$ & $\begin{array}{l}\text { Anti-inflammatory. } \\
\text { Anti-carcinogenic. } \\
\text { Suppresses ER } \alpha \text {. } \\
\text { Increases ER } \beta \text {. } \\
\text { Reduces cortisol. } \\
\text { Normalizes thyroid hormone levels } \\
\text { No direct hair growth studies, but } \\
\text { effect on circulating cortisol and T3 } \\
\text { will impact hair growth. }\end{array}$ \\
\hline $\begin{array}{c}\text { Horsetail } \\
\text { (Equisetum arvense) }\end{array}$ & $\begin{array}{l}\text { Used in traditional medicine and has strong } \\
\text { anti-inflammatory and antioxidant } \\
\text { properties [73]. Down-regulates TNF- } \alpha \text { and } \\
\text { upregulates anti-inflammatory IL-10 in } \\
\text { rheumatoid arthritis patients [132]. } \\
\text { Suppresses free radicals and inflammatory } \\
\text { mediators in IFN- } \gamma \text { and LPS-stimulated } \\
\text { murine macrophages [133]. }\end{array}$ & $\begin{array}{l}\text { Extracts demonstrate antioxidative effects in } \\
\text { two lipid peroxidation systems and } \\
\text { anti-proliferative activity in human tumor } \\
\text { cell lines [134]. }\end{array}$ & $\begin{array}{l}\text { Extracts inhibit } 5 \alpha \text {-reductase and decrease IL-6 } \\
\text { secretion in LPS-stimulated macrophages and are } \\
\text { not toxic against human follicle dermal papilla cells } \\
\text { [135]. }\end{array}$ & $\begin{array}{l}\text { Anticarcinogenic. } \\
\text { Anti-inflammatory. } \\
\text { Antioxidant. } \\
5 \alpha \text {-reductase inhibitor. }\end{array}$ \\
\hline
\end{tabular}


Table 1. Cont

\begin{tabular}{|c|c|c|c|c|}
\hline NUTRACEUTICAL & PROPERTIES & BREAST CANCER & HAIR GROWTH & $\begin{array}{l}\text { POTENTIAL } \\
\text { ADJUVANT }\end{array}$ \\
\hline Astaxanthin & $\begin{array}{l}\text { A carotenoid produced by Haematococcus } \\
\text { pluvialis (fresh-water algae). This blood-red } \\
\text { pigment accumulates when algae are } \\
\text { subjected to stress [67]. A powerful } \\
\text { antioxidant, superior to other carotenoids. It } \\
\text { preserves membrane integrity by insertion in } \\
\text { the bilayer, protecting the redox state and } \\
\text { mitochondrial function. It decreases ROS } \\
\text { and increases production of antioxidants, } \\
\text { e.g., catalase, GSH and SOD }[68,69] \text {. }\end{array}$ & $\begin{array}{l}\text { In ER +ve MCF-7 cells, it causes a significant } \\
\text { accumulation of cells in the G2/M phase } \\
\text { [136]. It significantly reduces proliferation } \\
\text { and migration of MCF-7 cells [137] and, after } \\
24 \text { hours, leads to a significant decrease in } \\
\text { viability [138]. It also significantly reduces } \\
\text { T47D viability in a dose-dependent manner } \\
\text { [139]. Its ability to reduce proliferation and } \\
\text { viability and to increase apoptosis of cancer } \\
\text { cells is associated with an increased } \\
\text { expression of PPAR } \gamma \text { [140]. Another } \\
\text { mechanism by which it inhibits breast cancer } \\
\text { cells by reducing proliferation is via } \\
\text { inactivation of the PI3K/AKT pathway [140]. }\end{array}$ & $\begin{array}{l}\text { Dysfunction of mitochondrial respiration delays hair } \\
\text { regeneration [141]. Astaxanthin can protect } \\
\text { mitochondria from oxidative damage by helping the } \\
\text { scavenging of ROS from follicle cells [68]. }\end{array}$ & $\begin{array}{l}\text { Powerful antioxidant. } \\
\text { Anti-carcinogenic. } \\
\text { Has potential to improve hair } \\
\text { growth by protecting from } \\
\text { oxidative stress. }\end{array}$ \\
\hline $\begin{array}{c}\text { Kelp } \\
\text { (brown seaweed) }\end{array}$ & $\begin{array}{l}\text { Brown seaweeds rich in polysaccharides (e.g., } \\
\text { alginic acid and fucoidan), vitamin B12, iron, } \\
\text { iodine, phlorotannins and fucoxanthin, with } \\
\text { biological properties [142]. } \\
\text { In rats, it has a dual action as an antagonistic } \\
\text { of ER } \alpha \text { and as an aromatase inhibitor, } \\
\text { suggesting a protective role in the initiation } \\
\text { and progression of estrogen-dependent } \\
\text { cancers [65]. }\end{array}$ & $\begin{array}{l}\text { Treatment of MCF-7 and MDA-MB-231 } \\
\text { breast cancer cells with Sargassum muticum } \\
\text { methanol extract significantly inhibits } \\
\text { proliferation and angiogenesis and increases } \\
\text { apoptosis in a time- and dose-dependent } \\
\text { manner [65,143]. Polysaccharides from } \\
\text { Sargassum wightii induce apoptosis of MCF7 } \\
\text { and MDA-MB-231 cells by increasing ROS, } \\
\text { mitochondrial membrane cleavage and } \\
\text { nuclei damage [144]. In animal models of } \\
\text { breast cancer, fucoidan, one of the main } \\
\text { polysaccharides in seaweed, stimulated an } \\
\text { immune response [145]. As an adjuvant it } \\
\text { increased sensitization to radiation and } \\
\text { chemotherapy in breast cancer cells and } \\
\text { animal models [146-148]. The } \\
\text { co-administration of fucoidan on } \\
\text { pharmacokinetics of letrozole and tamoxifen } \\
\text { in patients with breast cancer showed it was } \\
\text { well tolerated and did not alter plasma } \\
\text { concentration of the drugs [149]. }\end{array}$ & $\begin{array}{l}\text { An extract from brown seaweed Undariopsis } \\
\text { peterseniana, rich in fucoxanthinone, promoted hair } \\
\text { growth in rat hair follicles ex vivo and stimulated rat } \\
\text { dermal papilla cell proliferation by activating the } \\
\text { Wnt//-Catenin pathway [150]. The brown alga } \\
\text { Ecklonia cava, rich in phlorotannins, stimulated } \\
\text { human follicle dermal papilla cell proliferation and } \\
\text { hair fiber elongation in human hair follicles ex vivo } \\
\text { and hair growth in mice [151,152]. Fucoidan, a } \\
\text { prominent polysaccharide in brown seaweed, } \\
\text { stimulated production of HGF, which stimulates the } \\
\text { hair cycle [153,154]. A patent on fucoidan as a } \\
\text { hair-restoring agent was filed in } 2000 \text { (EP1234568B1). } \\
\text { A double-blinded, placebo-controlled clinical trial } \\
\text { showed seaweed extracts in supplements helped to } \\
\text { prevent patterned hair loss and promoted scalp } \\
\text { health in men and women [155]. A study on mice } \\
\text { showed a mixture of seaweed extracts was as } \\
\text { effective for hair growth promotion as minoxodil } \\
\text { [156]. }\end{array}$ & $\begin{array}{l}\text { Anti-carcinogenic. } \\
\text { Does not interfere with plasma } \\
\text { levels of tamoxifen or aromatase } \\
\text { inhibitors. } \\
\text { Contains supplements important } \\
\text { for hair growth, e.g., B12 and iron } \\
\text { [77]. Direct effects on dermal } \\
\text { papilla cells and hair growth. }\end{array}$ \\
\hline
\end{tabular}


Table 1. Cont.

\begin{tabular}{|c|c|c|c|c|}
\hline NUTRACEUTICAL & PROPERTIES & BREAST CANCER & HAIR GROWTH & $\begin{array}{l}\text { POTENTIAL } \\
\text { ADJUVANT }\end{array}$ \\
\hline $\begin{array}{l}\text { Malus pumila Miller } \mathrm{cv} \text {. } \\
\text { Annurca (apple fruits) }\end{array}$ & $\begin{array}{l}\text { Polyphenols with a high content of } \\
\text { oligomeric procyanidins, specifically } \\
\text { procyanidin B2. }\end{array}$ & $\begin{array}{l}\text { Apple polyphenolic compounds had a } \\
\text { significant antiproliferative action on MCF-7 } \\
\text { cells. An amount of } 500 \mu \mathrm{M} \text { of Annurca flesh } \\
\text { polyphenols extract (AFPE) induced a cell } \\
\text { cycle arrest at G2/M. AFPE was also capable } \\
\text { of inducing morphological changes as } \\
\text { evidenced by nuclear condensation [157]. }\end{array}$ & $\begin{array}{l}\text { Significantly stimulates the synthesis of cytokeratins } \\
\text { in the human keratinocyte HaCaT cell line [78] and } \\
\text { primary cultures of human hair keratinocytes [158] } \\
\text { in vitro and protects cultured human dermal papilla } \\
\text { from oxidative stress [158]. Oral supplementation } \\
\text { ( } 800 \mathrm{mg} \text { ) significantly increased hair growth, density } \\
\text { and keratin content in a cohort of } 250 \text { patients (116 } \\
\text { men and } 134 \text { women; } 30-83 \text { years of age) randomly } \\
\text { divided into two subgroups (each one of } 125 \\
\text { subjects, } 58 \text { men and } 67 \text { women) after } 2 \text { months [78]. }\end{array}$ & $\begin{array}{l}\text { Strong antioxidant. } \\
\text { Anti-carcinogenic. } \\
\text { Stimulates keratin synthesis. } \\
\text { Stimulates hair growth and density. }\end{array}$ \\
\hline $\begin{array}{l}\text { Carthamus Tinctorius L. } \\
\text { (Safflower) }\end{array}$ & $\begin{array}{l}\text { Active constituents include flavonoids, } \\
\text { phenylethanoid glycosides, coumarins, fatty } \\
\text { acids and steroids. Its oil has high nutritional } \\
\text { value, consisting of } 70 \% \text { polyunsaturated } \\
\text { fatty acid (i.e., linoleic acid) and } 10 \% \\
\text { monounsaturated oleic acid. }\end{array}$ & $\begin{array}{l}\text { Significantly increases apoptotic rate of the } \\
\text { MCF-7 cells in a dose-dependent manner by } \\
\text { down-regulating expression of Bcl-2 and } \\
\text { upregulating Bcl-2-associated X protein in a } \\
\text { time-dependent manner. Additionally, it } \\
\text { significantly reduced expression of MMP-9 } \\
\text { increased expression of TIMP-1 [159]. }\end{array}$ & $\begin{array}{l}\text { Suppresses the expression of TGF- } \beta 1 \text { and } \\
\text { significantly increases length of hair follicles in } \\
\text { culture by stimulating the expression of VEGF and } \\
\text { KGF [160]. Promotes hair growth, at least in part, by } \\
\text { upregulating expression of } \beta \text {-catenin [161]. }\end{array}$ & $\begin{array}{l}\text { Antioxidant. } \\
\text { Anti-inflammatory. } \\
\text { Anti-carcinogenic. } \\
\text { Stimulates hair growth. }\end{array}$ \\
\hline Capsicum aпnuит & $\begin{array}{l}\text { Chile pepper with high phenolic content and } \\
\text { antioxidant activity. }\end{array}$ & $\begin{array}{l}\text { Capsaicin is potent inhibiter of ER +ve } \\
\text { (MCF-7, T47D, BT-474) and ER-ve (SKBR-3, } \\
\text { MDA-MB231) breast cancer cell lines, } \\
\text { associated with G0/G1 cell-cycle arrest, } \\
\text { increased levels of apoptosis and reduced } \\
\text { protein expression of human epidermal } \\
\text { growth factor receptor (EGFR), HER2, } \\
\text { activated extracellular-regulated kinase } \\
\text { (ERK) and cyclin D1. Further blocked breast } \\
\text { cancer cell migration in vitro and decreased } \\
\text { tumors by 50\%, growing orthotopically in } \\
\text { immunodeficient mice [162]. }\end{array}$ & $\begin{array}{l}\text { Significantly increases IGF-I production in har } \\
\text { follicles, promoting hair growth [163]. Capsaicin as } \\
\text { an isolated active, when injected intradermally into } \\
\text { the back skin of C57BL/6 mice with all follicles in the } \\
\text { telogen phase of hair cycle, induced significant hair } \\
\text { growth (anagen), which was associated with } \\
\text { substantial mast cell degranulation [164]. }\end{array}$ & \\
\hline
\end{tabular}


Table 1. Cont

\begin{tabular}{|c|c|c|c|c|}
\hline NUTRACEUTICAL & PROPERTIES & BREAST CANCER & HAIR GROWTH & $\begin{array}{l}\text { POTENTIAL } \\
\text { ADJUVANT }\end{array}$ \\
\hline Panax ginseng & $\begin{array}{l}\text { The three key ingredients are saponins } \\
\text { (ginsenoside), polysaccharides and phenolic } \\
\text { compounds. Ginsenosides are categorized } \\
\text { into two groups based on their chemical } \\
\text { structure, i.e., oleanane type (five-ring } \\
\text { structure) and dammarane type (four-ring } \\
\text { structure) [165]. }\end{array}$ & $\begin{array}{l}\text { Anticancer properties include induction of } \\
\text { apoptosis, blocking angiogenesis, and } \\
\text { inhibiting proliferation in cancer cell lines } \\
\text { including MCF-7. [166]. Inhibits breast } \\
\text { cancer cell proliferation and both } \\
\text { anchorage-dependent and -independent } \\
\text { breast cancer cell colony formation. In } \\
\text { addition, it decreased the stability of the } \\
\text { IGF-1R protein in breast cancer cells. } \\
\text { suggesting that IGF-1R is an important target } \\
\text { for treatment and prevention of breast cancer } \\
\text { [167]. }\end{array}$ & $\begin{array}{l}\text { In clinical studies, red ginseng combined with } \\
\text { topical minoxidil increases its effectiveness at } \\
\text { promoting hair growth in human clinical studies. } \\
\text { Moreover, it promotes the proliferation of human } \\
\text { dermal follicle papilla cells and keratinocytes and } \\
\text { enhances hair anagen in the mouse [165]. In } \\
\text { chemotherapy-induced alopecia, it can protect } \\
\text { against premature catagen [168], and in vitro, it has } \\
\text { been shown to stimulate proliferation and inhibit } \\
\text { apoptosis in hair follicle outer root sheath } \\
\text { keratinocytes [169]. }\end{array}$ & $\begin{array}{l}\text { Anti-carcinogenic. } \\
\text { Antioxidant. } \\
\text { Anti-inflammatory. }\end{array}$ \\
\hline \multicolumn{5}{|c|}{ 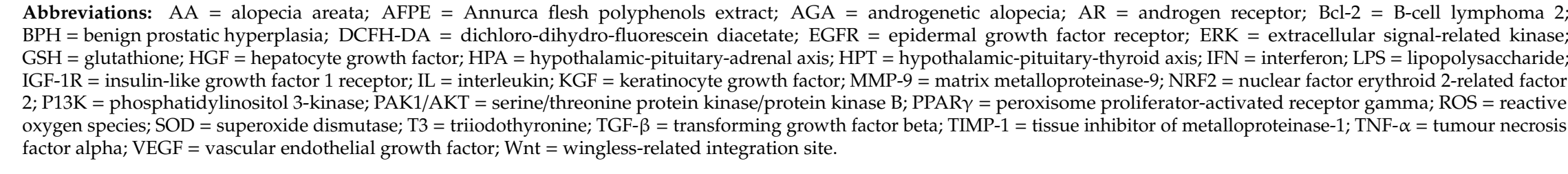 } \\
\hline
\end{tabular}




\section{Discussion}

This review has highlighted an important role for sex hormones in the development of FPHL and that endocrine therapy in the form of tamoxifen and/or aromatase inhibitors for the management of breast cancer can induce ETIHL. For some women, this is a considerable side effect which can significantly impact the quality of life and, in some cases, non-compliance of necessary endocrine treatment. For many women, breast cancer treatment may also include chemotherapy, which causes a dramatic increase in the level of free radicals and reactive oxygen species in the body. Since $17 \beta$-estradiol can also act as an antioxidant, its eradication with aromatase inhibitors can further exacerbate the problem.

Common intervention treatments are supplements containing vitamins and omega fatty acids; however, botanicals have a much higher therapeutic potential, although with medical professionals having some concerns around ER activity and activation. While some physicians have concerns around the use of plant-based nutraceuticals to treat hair loss in women that are undergoing endocrine therapy for the treatment of breast cancer, there is evidence to show that nutraceuticals such as curcumin, ashwagandha, maca, Annurca apple fruits, safflower and ginseng do not stimulate the proliferation of breast cancer cells. This may be due to both their tissue selectivity (SERMs with antagonistic properties in breast cancer cells) or their higher affinity for ER $\beta$. If these compounds have SERM activity, the ideal scenario is that their activity is as an antagonist in breast cancer cells and is an agonist in the hair follicle. Since the predominant ER in the human hair follicle is ER $\beta$ and in breast cancer cells it is $\mathrm{ER} \alpha$, then their relative affinity for these two distinct receptors is also of importance. Furthermore, there is evidence to show that nutraceuticals such as curcumin, tocotrienols, kelp, ashwagandha and resveratrol, in addition to exerting an anti-proliferative effect on breast cancer cells, can also downregulate $\operatorname{ER} \alpha$ while stabilizing the anti-proliferative $\operatorname{ER} \beta$, thereby altering the $\operatorname{ER} \alpha: \operatorname{ER} \beta$ ratio. In addition, Capsicum annuum extracted from chilies can also reduce the expression of HER2 in breast cancer cells. Therefore, the potential use of any of these nutraceuticals to promote hair growth in women should not pose an increased risk of breast cancer.

However, more extensive studies are required to understand how these nutraceuticals can modulate ER expression in breast cancer cells, or whether they actually have no interaction with the ERs and purely have anti-inflammatory and/or antioxidant actions. Indeed, all of them exhibit anti-inflammatory and antioxidant activity and it may be that since many of them are polyphenols, this is their mode of action. The epidermal matrix cells of the anagen hair follicle are the second highest proliferative cells in the human body, which is why hair is so drastically impacted by chemotherapy. Consequently, the hair follicle is susceptible to oxidative stress and the antioxidant mechanism action of these nutraceuticals may be the main driving force behind their stimulatory/protective influence.

The most important aspect of ingredient safety in supplements that can improve ETIHL for women undergoing breast cancer treatment is that the ingredients should not be acting as estrogen that stimulates the proliferation of breast cancer cells in postmenopausal women, or that they compete with the antagonistic action of tamoxifen. Therefore, understanding their mechanism of action is key, since many women will be prescribed endocrine-directed therapy in the form of tamoxifen, aromatase inhibitors or Herceptin. Although the exact mechanisms are unclear, this literature review highlights evidence advocating that supplements containing resveratrol, saw palmetto, maca, curcumin, tocotrienols, ashwagandha, horsetail, astaxanthin, kelp, capsicum, Annurca apple fruits, safflower and ginseng can have beneficial effects on hair growth, without adverse effects on breast cancer patients.

Author Contributions: Conceptualization, M.J.T. and G.D.; original draft preparation, M.J.T. and G.D.; preparation of figures, M.J.T.; review and editing, M.J.T., G.D. and A.R. All authors have read and agreed to the published version of the manuscript.

Funding: M.J.T. has received external funding via a research collaboration with Nutraceuticals Wellness, Inc.

Conflicts of Interest: G.D. is a consultant at Nutraceuticals Wellness, Inc. and A.R. is an employee at Nutraceuticals Wellness, Inc. 


\section{References}

1. Gruber, C.J.; Tschugguel, W.; Schneeberger, C.; Huber, J.C. Production and actions of estrogens. N. Engl. J. Med. 2002, 346, 340-352. [CrossRef] [PubMed]

2. Ghoncheh, M.; Pournamdar, Z.; Salehiniya, H. Incidence and Mortality and Epidemiology of Breast Cancer in the World. Asian Pac. J. Cancer Prev. 2016, 17, 43-46. [CrossRef] [PubMed]

3. Dall, G.V.; Britt, K.L. Estrogen Effects on the Mammary Gland in Early and Late Life and Breast Cancer Risk. Front. Oncol. 2017, 7, 110. [CrossRef] [PubMed]

4. Clemons, M.; Goss, P. Estrogen and the risk of breast cancer. N. Engl. J. Med. 2001, 344, 276-285. [CrossRef] [PubMed]

5. Yue, W.; Wang, J.P.; Li, Y.; Fan, P.; Liu, G.; Zhang, N.; Conaway, M.; Wang, H.; Korach, K.S.; Bocchinfuso, W.; et al. Effects of estrogen on breast cancer development: Role of estrogen receptor independent mechanisms. Int. J. Cancer 2010, 127, 1748-1757. [CrossRef] [PubMed]

6. Li, J.; Chen, Z.; Su, K.; Zeng, J. Clinicopathological classification and traditional prognostic indicators of breast cancer. Int. J. Clin. Exp. Pathol. 2015, 8, 8500-8505.

7. Fortner, R.T.; Sisti, J.; Chai, B.; Collins, L.C.; Rosner, B.; Hankinson, S.E.; Tamimi, R.M.; Eliassen, A.H. Parity, breastfeeding, and breast cancer risk by hormone receptor status and molecular phenotype: Results from the Nurses' Health Studies. Breast Cancer Res. 2019, 21, 40. [CrossRef] [PubMed]

8. Mosselman, S.; Polman, J.; Dijkema, R. ER $\beta$. Identification and characterisation of a novel human estrogen receptor. FEBS Lett. 1996, 392, 49-53. [CrossRef]

9. Kuiper, G.G.; Enmark, E.; Pelto-Huikko, M.; Nilsson, S.; Gustafsson, J.A. Cloning of a novel receptor expressed in rat prostate and ovary. Proc. Natl. Acad. Sci. USA 1996, 93, 5925-5930. [CrossRef]

10. Cui., J.; Shen, Y.; Li, R. Estrogen synthesis and signaling pathways during aging: From periphery to brain. Trends Mol. Med. 2013, 19, 197-209. [CrossRef]

11. Klinge, C.M. Estrogen receptor interaction with estrogen response elements. Nucleic Acids Res. 2001, 29, 2905-2919. [CrossRef] [PubMed]

12. Webb, P.; Nguyen, P.; Kushner, P.J. Differential SERM effects on corepressor binding dictate ERalpha activity in vivo. J. Biol. Chem. 2003, 278, 6912-6920. [CrossRef] [PubMed]

13. Paech, K.; Webb, P.; Kuiper, G.G.; Nilsson, S.; Gustafsson, J.; Kushner, P.J.; Scanlan, T.S. Differential ligand activation of estrogen receptors ERalpha and ERbeta at AP1 sites. Science 1997, 277, 1508-1510. [CrossRef] [PubMed]

14. Evers, N.M.; van den Berg, J.H.J.; Wang, S.; Melchers, D.; Houtman, R.; de Haan, L.H.J.; Ederveen, A.G.H.; Groten, J.P.; Rietjens, I.M.C.M. Cell proliferation and modulation of interaction of estrogen receptors with coregulators induced by ER $\alpha$ and ER $\beta$ agonists. J. Steroid Biochem. Mol. Biol. 2014, 143, 376-385. [CrossRef] [PubMed]

15. Levin, E.R. Minireview: Extranuclear steroid receptors: Roles in modulation of cell functions. Mol. Endocrinol. 2011, 25, 377-384. [CrossRef]

16. Pedram, A.; Razandi, M.; Sainson, R.C.; Kim, J.K.; Hughes, C.C.; Levin, E.R. A conserved mechanism for steroid receptor translocation to the plasma membrane. J. Biol. Chem. 2007, 282, 22278-22288. [CrossRef]

17. Levin, E.R. G-protein-coupled receptor 30: Estrogen receptor or collaborator? Endocrinology 2009, 150, 1563-1565. [CrossRef] [PubMed]

18. Santen, R.J.; Fan, P.; Zhang, Z.; Bao, Y.; Song, R.X.; Yue, W. Estrogen signals via an extra-nuclear pathway involving IGF-1R and EGFR in tamoxifen-sensitive and -resistant breast cancer cells. Steroids 2009, 74, 586-594. [CrossRef] [PubMed]

19. Yager, J.D.; Davidson, N.E. Estrogen carcinogenesis in breast cancer. N. Engl. J. Med. 2006, 354, $270-282$. [CrossRef]

20. Preston-Martin, S.; Pike, M.C.; Ross, R.K.; Jones, P.A.; Henderson, B.E. Increased cell division as a cause of human cancer. Cancer Res. 1990, 50, 7415-7421.

21. Song, P.; Li, Y.; Dong, Y.; Liang, Y.; Qu, H.; Qi, D.; Lu, Y.; Jin, X.; Guo, Y.; Jia, Y.; et al. Estrogen receptor $\beta$ inhibits breast cancer cells migration and invasion through CLDN6-mediated autophagy. J. Exp. Clin. Cancer Res. 2019, 38, 354. [CrossRef]

22. Hartman, J.; Lindberg, K.; Morani, A.; Inzunza, J.; Strom, A.; Gustafsson, J.A. Estrogen receptor beta inhibits angiogenesis and growth of T47D breast cancer xenografts. Cancer Res. 2006, 66, 11207-11213. [CrossRef] 
23. Song, W.; Tang, L.; Xu, Y.; Sun, Q.; Yang, F.; Guan, X. ERbeta1 inhibits metastasis of androgen receptor-positive triple-negative breast cancer by suppressing ZEB1. J. Exp. Clin. Cancer Res. 2017, 36, 75. [CrossRef]

24. Ruddy, S.C.; Lau, R.; Cabrita, M.A.; McGregor, C.; McKay, B.C.; Murphy, L.C.; Wright, J.S.; Durst, T.; Pratt, M.A.C. Preferential estrogen receptor beta ligands reduce Bcl-2 expression in hormone-resistant breast cancer cells to increase autophagy. Mol. Cancer Ther. 2014, 13, 1882-1893. [CrossRef]

25. Salhab, M.; Reed, M.; Al Sarakbi, W.; Jiang, W.G.; Mokbel, K. The role of aromatase and $17 \beta$ hydroxysteroid dehydrogenase type 1 mRNA expression in predicting the clinical outcome of human breast cancer. Breast Cancer Res. Treat. 2006, 99, 155-162. [CrossRef]

26. Santen, R.J.; Martel, J.; Hoagland, M.; Naftolin, F.; Roa, L.; Harada, N.; Hafer, L.; Zaino, R.; Pauley, R.; Santner, S. Demonstration of aromatase activity and its regulation in breast tumor and benign breast fibroblasts. Breast Cancer Res. Treat. 1998, 49 (Suppl. 9), S93-S99. [CrossRef]

27. Blakemore, J.; Naftolin, F. Aromatase: Contributions to Physiology and Disease in Women and Men. Physiology 2016, 31, 258-269. [CrossRef]

28. Bogush, T.A.; Polezhaev, B.B.; Mamichev, I.A.; Bogush, E.A.; Polotsky, B.E.; Tjulandin, S.A.; Ryabov, A.B. Tamoxifen Never Ceases to Amaze: New Findings on Non-Estrogen Receptor Molecular Targets and Mediated Effects. Cancer Investig. 2018, 36, 211-220. [CrossRef]

29. Sainsbury, R. The development of endocrine therapy for women with breast cancer. Cancer Treat. Rev. 2013, 39, 507-517. [CrossRef]

30. McDonald, E.S.; Clark, A.S.; Tchou, J.; Zhang, P.; Freedman, G.M. Clinical Diagnosis and Management of Breast Cancer. J. Nucl. Med. 2016, 57, 9S-16S. [CrossRef]

31. Bergin, A.R.T.; Loi, S. Triple-negative breast cancer: Recent treatment advances. F1000 Res. 2019, 8, 1342. [CrossRef] [PubMed]

32. Droog, M.; Beelen, K.; Linn, S.; Zwart, W. Tamoxifen resistance: From bench to bedside. Eur. J. Pharmacol. 2013, 717, 47-57. [CrossRef] [PubMed]

33. Hachisuga, T.; Miyakawa, T.; Tsujioka, H.; Horiuchi, S.; Emoto, M.; Kawarabayashi, T. K-ras mutation in tamoxifen-related endometrial polyps. Cancer 2003, 98, 1890-1897. [CrossRef] [PubMed]

34. Jordan, V.C. The Past, Present, and Future of Selective Estrogen Receptor Modulation. Ann. N. Y. Acad. Sci. 2001, 949, 72-79. [CrossRef]

35. Karatas, F.; Sahin, S.; Sever, A.R.; Altundag, K. Management of hair loss associated with endocrine therapy in patients with breast cancer: An overview. Springerplus 2016, 5, 585. [CrossRef]

36. Randall, V.A.; Hibberts, N.A.; Thornton, M.J.; Hamada, K.; Merrick, A.E.; Kato, S.; Jenner, T.J.; De Oliveira, I.; Messenger, A.G. The hair follicle: A paradoxical androgen target organ. Horm Res. 2000, 54, 243-250. [CrossRef]

37. Randall, V.A.; Ebling, F.J. Seasonal changes in human hair growth. Br. J. Dermatol. 1991, 124, $146-151$. [CrossRef]

38. Lynfield, Y.L. Effect of pregnancy on the human hair cycle. J. Investig. Dermatol. 1960, 35, 323-327. [CrossRef]

39. Labrie, F. Intracrinology and menopause: The science describing the cell-specific intracellular formation of estrogens and androgens from DHEA and their strictly local action and inactivation in peripheral tissues. Menopause 2019, 26, 220-224. [CrossRef]

40. Chen, W.; Yang, C.-C.; Todorova, A.; Al Khuzaei, S.; Chiu, H.-C.; Worret, W.I.; Ring, J. Hair loss in elderly women. Eur. J. Dermatol. 2010, 20, 145-151. [CrossRef]

41. Yip, L.; Zaloumis, S.; Irwin, D.; Severi, G.; Hopper, J.; Giles, G.; Harrap, S.; Sinclair, R.; Ellis, J. Gene-wide association study between the aromatase gene (CYP19A1) and female pattern hair loss. Br. J. Dermatol. 2009, 161, 289-294. [CrossRef] [PubMed]

42. Yip, L.; Zaloumis, S.; Irwin, D.; Severi, G.; Hopper, J.; Giles, G.; Harrap, S.; Sinclair, R.; Ellis, J. Association analysis of oestrogen receptor beta gene (ESR2) polymorphisms with female pattern hair loss. Br. J. Dermatol. 2012, 166, 1131-1134. [CrossRef] [PubMed]

43. Thornton, M.J.; Taylor, A.H.; Mulligan, K.; Al-Azzawi, F.; Lyon, C.; O’Driscoll, J.; Messenger, A.G. The distribution of estrogen receptor beta (ERbeta) is distinct to that of ERalpha and the androgen receptor in human skin and the pilosebaceous unit. J. Investig. Dermatol. Symp. Proc. 2003, 8, 100-103. [CrossRef] [PubMed] 
44. Stevenson, S.; Taylor, A.H.; Meskiri, A.; Sharpe, D.T.; Thornton, M.J. Differing responses of human follicular and nonfollicular scalp cells in an in vitro wound healing assay: Effects of estrogen on vascular endothelial growth factor secretion. Wound Repair Regen. 2008, 16, 243-253. [CrossRef]

45. Labrie, F. Adrenal androgens and intracrinology. Semin. Reprod. Med. 2004, 22, 299-309. [CrossRef]

46. Pomari, E.; Dalla Valle, L.; Pertile, P.; Colombo, L.; Thornton, M.J. Intracrine sex steroid synthesis and signaling in human epidermal keratinocytes and dermal fibroblasts. FASEB J. 2015, 29, 508-524. [CrossRef]

47. Slominski, A.; Zbytek, V.; Nikolakis, G.; Manna, P.R.; Skobowiat, C.; Zmijewski, M.; Li, W.; Janjetovic, Z.; Postlethwaite, A.; Zouboulis, C.C.; et al. Steroidogenesis in the skin: Implications for local immune functions. J. Steroid Biochem. Mol. Biol. 2013, 137, 107-123. [CrossRef]

48. Sawaya, M.E.; Price, V.H. Different levels of 5alpha-reductase type I and II, aromatase, and androgen receptor in hair follicles of women and men with androgenetic alopecia. J. Investig. Dermatol. 1997, 109, $296-300$. [CrossRef]

49. Sánchez, P.; Serrano-Falcón, C.; Torres, J.M.; Serranoortega, S.; Ortega, E. $5 \alpha$-Reductase isozymes and aromatase mRNA levels in plucked hair from young women with female pattern hair loss. Arch. Dermatol. Res. 2018, 310, 77-83. [CrossRef]

50. Rebora, A.; Guarrera, M. Kenogen. A new phase of the hair cycle? Dermatology 2002, 205, 108-110. [CrossRef]

51. Gallicchio, L.; Calhoun, C.; Helzlsouer, K.J. Aromatase inhibitor therapy and hair loss among breast cancer survivors. Breast Cancer Res. Treat. 2013, 142, 435-443. [CrossRef] [PubMed]

52. Saggar, V.; Wu, S.; Dickler, M.N.; Lacouture, M.E. Alopecia with endocrine therapies in patients with cancer. Oncologist 2013, 18, 1126-1134. [CrossRef] [PubMed]

53. Rossi, A.; Iorio, A.; Scali, E.; Fortuna, M.; Mari, E.; Maxia, C.; Gerardi, M.; Framarino, M.; Carlesimo, M. Aromatase inhibitors induce 'male pattern hair loss' in women? Ann. Oncol. 2013, 24, 1710-1711. [CrossRef] [PubMed]

54. Gateley, C.; Bundred, N. Alopecia and breast disease. Br. Med. J. 1997, 314, 481. [CrossRef] [PubMed]

55. Freites-Martinez, A.; Shapiro, J.; Chan, D.; Fornier, M.; Modi, S.; Gajria, D.; Dusza, S.; Goldfarb, S.; Lacouture, M.E. Endocrine Therapy-Induced Alopecia in Patients with Breast Cancer. JAMA Dermatol. 2018, 154, 670-675. [CrossRef] [PubMed]

56. Park, J.; Kim, J.; Yun, S.K.; Kim, H.U.; Ihm, C.W. Pattern Alopecia during Hormonal Anticancer Therapy in Patients with Breast Cancer. Ann. Dermatol. 2014, 26, 743-746. [CrossRef]

57. Richardson, T.E.; Yang, S.H.; Wen, Y.; Simpkins, J.W. Estrogen protection in Friedreich's ataxia skin fibroblasts. Endocrinology 2011, 152, 2742-2749. [CrossRef]

58. Prokai, L.; Prokai-Tatrai, K.; Perjesi, P.; Zharikova, A.D.; Perez, E.J.; Liu, R.; Simpkins, J.W. Quinol-based cyclic antioxidant mechanism in estrogen neuroprotection. Proc. Natl. Acad. Sci. USA 2003, 100, 11741-11746. [CrossRef]

59. Richardson, T.E.; Yu, A.E.; Wen, Y.; Yang, S.H.; Simpkins, J.W. Estrogen prevents oxidative damage to the mitochondria in Friedreich's ataxia skin fibroblasts. PLoS ONE 2012, 7, e34600. [CrossRef]

60. Behl, C.; Holsboer, F. The female sex hormone oestrogen as a neuroprotectant. Trends Pharmacol. Sci. 1999, 20, 441-444. [CrossRef]

61. Baker, M.E.; Lathe, R. The promiscuous estrogen receptor: Evolution of physiological estrogens and response to phytochemicals and endocrine disruptors. J. Steroid Biochem. Mol. Biol. 2018, 184, 29-37. [CrossRef] [PubMed]

62. Hwang, C.S.; Kwak, H.S.; Lim, H.J.; Lee, S.H.; Kang, Y.S.; Choe, T.B.; Hur, H.G.; Han, K.O. Isoflavone metabolites and their in vitro dual functions: They can act as an estrogenic agonist or antagonist depending on the estrogen concentration. J. Steroid Biochem. Mol. Biol. 2006, 101, 246-253. [CrossRef] [PubMed]

63. Robb, E.L.; Stuart, J.A. Resveratrol interacts with estrogen receptor- $\beta$ to inhibit cell replicative growth and enhance stress resistance by upregulating mitochondrial superoxide dismutase. Free Radic. Biol. Med. 2011, 50, 821-831. [CrossRef] [PubMed]

64. Kabir, M.; Adnan, M.; Rahman, M.M. Natural Sources of Tocotrienols: A Note on Absorption. J. In Silico In Vitr. Pharmacol. 2017, 3, 20. [CrossRef]

65. Zhang, J.; Riby, J.E.; Conde, L.; Grizzle, W.E.; Cui, X.; Skibola, C.F. A Fucus vesiculosus extract inhibits estrogen receptor activation and induces cell death in female cancer cell lines. BMC Complement. Altern. Med. 2016, 16, 151. [CrossRef] 
66. Hosking, A.M.; Juhasz, M.; Mesinkovska, N.A. Complementary and Alternative Treatments for Alopecia: A Comprehensive Review. Ski. Appendage Disord. 2019, 5, 72-89. [CrossRef]

67. Sarada, R.; Tripathi, U.; Ravishankar, G.A. Influence of stress on astaxanthin production in Haematococcus pluvialis grown under different culture conditions. Process. Biochem. 2002, 37, 623-627. [CrossRef]

68. Davinelli, S.; Nielsen, M.E.; Scapagnini, G. Astaxanthin in Skin Health, Repair, and Disease: A Comprehensive Review. Nutrients 2018, 10, 522. [CrossRef]

69. Higuera-Ciapara, I.; Felix-Valenzuela, L.; Goycoolea, F.M. Astaxanthin: A review of its chemistry and applications. Crit. Rev. Food Sci. Nutr. 2016, 46, 185-196. [CrossRef]

70. Bai, N.; He, K.; Roller, M.; Lai, C.S.; Bai, L.; Pan, M.H. Flavonolignans and other constituents from Lepidium meyenii with activities in anti-inflammation and human cancer cell lines. J. Agric. Food Chem. 2015, 63, 2458-2463. [CrossRef]

71. Soundararajan, P.; Kim, J.S. Anti-Carcinogenic Glucosinolates in Cruciferous Vegetables and Their Antagonistic Effects on Prevention of Cancers. Molecules 2018, 23, 2983. [CrossRef] [PubMed]

72. Liczbiński, P.; Michałowicz, J.; Bukowska, B. Molecular mechanism of curcumin action in signaling pathways: Review of the latest research. Phytother. Res. 2020, 34, 1992-2005. [CrossRef] [PubMed]

73. Asgarpanah, J.; Roohi, E. Phytochemistry and pharmacological properties of Equisetum arvense L. J. Med. Plants Res. 2012, 6, 3689-3693. [CrossRef]

74. Dar, N.J.; Hamid, A.; Ahmad, M. Pharmacologic overview of Withania somnifera, the Indian Ginseng. Cell Mol. Life Sci. 2015, 72, 4445-4460. [CrossRef] [PubMed]

75. Hahm, E.R.; Lee, J.; Huang, Y.; Singh, S.V. Withaferin a suppresses estrogen receptor- $\alpha$ expression in human breast cancer cells. Mol. Carcinog. 2011, 50, 614-624. [CrossRef] [PubMed]

76. Le Floc'h, C.; Cheniti, A.; Connétable, S.; Piccardi, N.; Vincenzi, C.; Tosti, A. Effect of a nutritional supplement on hair loss in women. J. Cosmet. Dermatol. 2015, 14, 76-82.

77. Rushton, D.H. Nutritional factors and hair loss. Clin. Exp. Dermatol. 2002, 27, 396-404. [CrossRef]

78. Tenore, G.C.; Caruso, D.; Buonomo, G.; D’Avino, M.; Santamaria, R.; Irace, C.; Piccolo, M.; Maisto, M.; Novellino, E. Annurca Apple Nutraceutical Formulation Enhances Keratin Expression in a Human Model of Skin and Promotes Hair Growth and Tropism in a Randomized Clinical Trial. J. Med. Food. 2018, 21, 90-103. [CrossRef]

79. Singh, B.; Shoulson, R.; Chatterjee, A.; Ronghe, A.; Bhat, N.K.; Dim, D.C.; Bhat, H.K. Resveratrol inhibits estrogen-induced breast carcinogenesis through induction of NRF2-mediated protective pathways. Carcinogenesis 2014, 35, 1872-1880. [CrossRef]

80. Pozo-Guisado, E.; Merino, J.M.; Mulero-Navarro, S.; Lorenzo-Benayas, M.J.; Centeno, F.; Alvarez-Barrientos, A.; Fernandez-Salguero, P.M. Resveratrol-induced apoptosis in MCF-7 human breast cancer cells involves a caspase-independent mechanism with downregulation of Bcl-2 and NF-kappaB. Int. J. Cancer 2005, 115, 74-84. [CrossRef]

81. Ronghe, A.; Chatterjee, A.; Bhat, N.K.; Padhye, S.; Bhat, H.K. Tamoxifen synergizes with 4-(E)\{(4-hydroxyphenylimino)-methylbenzene, 1,2-diol\} and 4-(E)-\{(p-tolylimino)-methylbenzene-1,2-diol\}, novel azaresveratrol analogs, in inhibiting the proliferation of breast cancer cells. Oncotarget 2016, 7, 51747-51762. [CrossRef] [PubMed]

82. Juchaux, F.; Sellathurai, T.; Perrault, V.; Boirre, F.; Delannoy, P.; Bakkar, K.; Albaud, J.; Gueniche, A.; Cheniti, A.; Dal Belo, S.; et al. A combination of pyridine-2, 4-dicarboxylic acid diethyl ester and resveratrol stabilizes hypoxia-inducible factor 1-alpha and improves hair density in female volunteers. Int. J. Cosmet. Sci. 2020, 42,167-173. [CrossRef] [PubMed]

83. Nesaretnam, K.; Meganathan, P.; Veerasenan, S.D.; Selvaduray, K.R. Tocotrienols and breast cancer: The evidence to date. Genes Nutr. 2012, 7, 3-9. [CrossRef] [PubMed]

84. Comitato, R.; Nesaretnam, K.; Leoni, G.; Ambra, R.; Canali, R.; Bolli, A.; Marino, M.; Virgili, F.A. Novel mechanism of natural vitamin E tocotrienol activity: Involvement of ERbeta signal transduction. Am. J. Physiol. Endocrinol. Metab. 2009, 297, E427-E437. [CrossRef] [PubMed]

85. Comitato, R.; Guantario, B.; Leoni, G.; Nesaretnam, K.; Ronci, M.B.; Canali, R.; Virgili, F. Tocotrienols induce endoplasmic reticulum stress and apoptosis in cervical cancer cells. Genes Nutr. 2016, 11, 32. [CrossRef]

86. Guthrie, N.; Gapor, A.; Chambers, A.F.; Carroll, K.K. Inhibition of Proliferation of Estrogen Receptor-Negative MDA-MB-435 and -Positive MCF-7 Human Breast Cancer Cells by Palm Oil Tocotrienols and Tamoxifen, Alone and in Combination. J. Nutr. 1997, 127, 544S-548S. [CrossRef] 
87. Nesaretnam, K.; Selvaduray, K.R.; Abdul Razak, G.; Veerasenan, S.D.; Gomez, P.A. Effectiveness of tocotrienol-rich fraction combined with tamoxifen in the management of women with early breast cancer: A pilot clinical trial. Breast Cancer Res. 2010, 12, R81. [CrossRef]

88. Hsieh, T.C.; Elangovan, S.; Wu, J.M. Differential Suppression of Proliferation in MCF-7 and MDA-MB-231 Breast Cancer Cells Exposed to Alpha-, Gamma- And Delta-Tocotrienols Is Accompanied by Altered Expression of Oxidative Stress Modulatory Enzymes. Anticancer Res. 2010, 30, 4169-4176.

89. Ahmed, N.S.; Ghatak, S.; El Masry, M.S.; Gnyawali, S.C.; Roy, S.; Amer, M.; Everts, H.; Sen, C.K.; Khanna, S. Epidermal E-Cadherin Dependent $\beta$-Catenin Pathway is Phytochemical Inducible and Accelerates Anagen Hair Cycling. Mol. Ther. 2017, 25, 2502-2512. [CrossRef]

90. Beoy, L.A.; Woei, W.J.; Hay, Y.K. Effects of tocotrienol supplementation on hair growth in human volunteers. Trop. Life Sci Res. 2010, 21, 91-99.

91. Hostanska, K.; Suter, A.; Melzer, J.; Saller, R. Evaluation of cell death caused by an ethanolic extract of Serenoae repentis fructus (Prostasan) on human carcinoma cell lines. Anticancer Res. 2007, 27, 873-881. [PubMed]

92. Di Silverio, F.; D’Eramo, G.; Lubrano, C.; Flammia, G.P.; Sciarra, A.; Palma, E.; Caponera, M.; Sciarra, F. Evidence that Serenoa repens extract displays an antiestrogenic activity in prostatic tissue of benign prostatic hypertrophy patients. Eur. Urol. 1992, 21, 309-314. [CrossRef] [PubMed]

93. Strauch, G.; Perles, P.; Vergult, G.; Gabriel, M.; Gibelin, B.; Cummings, S.; Malbecq, W.; Malice, M.P. Comparison of finasteride (Proscar) and Serenoa repens (Permixon) in the inhibition of 5-alpha reductase in healthy male volunteers. Eur. Urol. 1994, 26, 247-252. [CrossRef] [PubMed]

94. Prager, N.; Bickett, K.; French, N.; Marcovici, G. A randomized, double-blind, placebo-controlled trial to determine the effectiveness of botanically derived inhibitors of 5-alpha-reductase in the treatment of androgenetic alopecia. J. Altern. Complement. Med. 2002, 8, 143-152. [CrossRef] [PubMed]

95. Rossi, A.; Mari, E.; Scarno, M.; Garelli, V.; Maxia, C.; Scali, E.; Iorio, A.; Carlesimo, M. Comparitive effectiveness of finasteride vs Serenoa repens in male androgenetic alopecia: A two-year study. Int. J. Immunopathol. Pharmacol. 2012, 25, 1167-1173. [CrossRef] [PubMed]

96. Wessagowit, V.; Tangjaturonrusamee, C.; Kootiratrakarn, T.; Bunnag, T.; Pimonrat, T.; Muangdang, N.; Pichai, P. Treatment of male androgenetic alopecia with topical products containing Serenoa repens extract. Australas. J. Dermatol. 2016, 57, 76-82. [CrossRef]

97. Večeřa, R.; Orolin, J.; Škottová, N.; Kazdová, L.; Oliyarnik, O.; Ulrichová, J.; Šimánek, V. The influence of maca (Lepidium meyenii) on antioxidant status, lipid and glucose metabolism in rat. Plant Foods Hum. Nutr. 2007, 62, 59-63. [CrossRef]

98. Fano, D.; Vásquez-Velásquez, C.; Gonzales-Castañeda, C.; Guajardo-Correa, E.; Orihuela, P.A.; Gonzales, G.F. N-Butanol and Aqueous Fractions of Red Maca Methanolic Extract Exerts Opposite Effects on Androgen and Oestrogens Receptors (Alpha and Beta) in Rats with Testosterone-Induced Benign Prostatic Hyperplasia. Evid. Based Complement. Altern. Med. 2017, 2017, 9124240. [CrossRef]

99. Meissner, H.O.; Mscisz, A.; Reich-Bilinska, H.; Mrozikiewicz, P.; Bobkiewicz-Kozlowska, T.; Kedzia, B.; Lowicka, A.; Barchia, I. Hormone-Balancing Effect of Pre-Gelatinized Organic Maca (Lepidium peruvianum Chacon): (III) Clinical responses of early-postmenopausal women to Maca in double blind, randomized, Placebo-controlled, crossover configuration, outpatient study. Int. J. Biomed. Sci. 2006, 2, 375-394.

100. Atwa, M.A.; Youssef, N.; Bayoumy, N.M. T-helper 17 cytokines (interleukins 17, 21, 22, and 6, and tumor necrosis factor- $\alpha$ ) in patients with alopecia areata: Association with clinical type and severity. Int. J. Dermatol. 2016, 55, 666-672. [CrossRef]

101. Gonzales, G.F.; Gasco, M.; Lozada-Requena, I. Role of maca (Lepidium meyenii) consumption on serum interleukin-6 levels and health status in populations living in the Peruvian Central Andes over $4000 \mathrm{~m}$ of altitude. Plant Foods Hum. Nutr. 2013, 68, 347-351. [CrossRef] [PubMed]

102. Prie, B.E.; Iosif, L.; Tivig, I.; Stoian, I.; Giurcaneanu, C. Oxidative stress in androgenetic alopecia. J. Med. Life 2016, 9, 79-83. [PubMed]

103. Zhou, H.; Beevers, C.S.; Huang, S. The targets of curcumin. Curr. Drug Targets 2011, 12, 332-347. [CrossRef] [PubMed]

104. Fadus, M.C.; Lau, C.; Bikhchandani, J.; Lynch, H.T. Curcumin: An age-old anti-inflammatory and anti-neoplastic agent. J. Tradit. Complement. Med. 2016, 7, 339-346. [CrossRef] 
105. Nejati-Koshki, K.; Akbarzadeh, A.; Pourhassan-Moghaddam, M. Curcumin inhibits leptin gene expression and secretion in breast cancer cells by estrogen receptors. Cancer Cell Int. 2014, 14, 66. [CrossRef]

106. Hallman, K.; Aleck, K.; Dwyer, B.; Lloyd, V.; Quigley, M.; Sitto, N.; Siebert, A.E.; Dinda, S. The effects of turmeric (curcumin) on tumor suppressor protein (p53) and estrogen receptor (ER $\alpha$ ) in breast cancer cells. Breast Cancer 2017, 9, 153-161.

107. Banik, U.; Parasuraman, S.; Adhikary, A.K.; Othman, N.H. Curcumin: The spicy modulator of breast carcinogenesis. J. Exp. Clin. Cancer Res. 2017, 36, 98. [CrossRef]

108. Singh, M.; Singh, N. Curcumin counteracts the proliferative effect of estradiol and induces apoptosis in cervical cancer cells. Mol. Cell Biochem. 2011, 347, 1-11. [CrossRef]

109. Zhang, Y.; Cao, H.; Yu, Z.; Peng, H.Y.; Zhang, C.J. Curcumin inhibits endometriosis endometrial cells by reducing estradiol production. Iran. J. Reprod. Med. 2013, 11, 415-422.

110. Jung, S.; Otberg, N.; Thiede, G.; Richter, H.; Sterry, W.; Panzner, S.; Lademann, J. Innovative liposomes as a transfollicular drug delivery system: Penetration into porcine hair follicles. J. Investig. Dermatol. 2006, 126, 1728-1732. [CrossRef]

111. Konrádsdóttir, F.; Ogmundsdóttir, H.; Sigurdsson, V.; Loftsson, T. Drug targeting to the hair follicles: A cyclodextrin-based drug delivery. AAPS PharmSciTech 2009, 10, 266-269. [CrossRef] [PubMed]

112. Nguyen, B.C.; Taira, N.; Maruta, H.; Tawata, S. Artepillin C and Other Herbal PAK1-blockers: Effects on Hair Cell Proliferation and Related PAK1-dependent Biological Function in Cell Culture. Phytother. Res. 2016, 30, 120-127. [CrossRef] [PubMed]

113. Huh, S.; Lee, J.; Jung, E.; Kim, S.C.; Kang, J.I.; Lee, J.; Kim, Y.W.; Sung, Y.K.; Kang, H.K.; Park, D. A cell-based system for screening hair growth-promoting agents. Arch. Dermatol. Res. 2009, 301, 381-385. [CrossRef] [PubMed]

114. Pumthong, G.; Asawanonda, P.; Varothai, S.; Jariyasethavong, V.; Triwongwaranat, D.; Suthipinittharm, P.; Ingkaninan, K.; Leelapornpisit, P.; Waranuch, N. Curcuma aeruginosa, a novel botanically derived $5 \alpha$-reductase inhibitor in the treatment of male-pattern baldness: A multicenter, randomized, double-blind, placebo-controlled study. J. Dermatol. Treat. 2012, 23, 385-392. [CrossRef] [PubMed]

115. Hassannia, B.; Logie, E.; Vandenabeele, P.; Vanden Berghe, T.; Vanden Berghe, W. Withaferin A: From ayurvedic folk medicine to preclinical anti-cancer drug. Biochem. Pharmacol. 2020, 173, 113602. [CrossRef]

116. Saggam, A.; Tillu, G.; Dixit, S.; Chavan-Gautam, P.; Borse, S.; Joshi, K.; Patwardhan, B. Withania somnifera (L.) Dunal: A potential therapeutic adjuvant in cancer. J. Ethnopharmacol. 2020, 255, 112759. [CrossRef]

117. Khazal, K.F.; Samuel, T.; Hill, D.L.; Grubbs, C.J. Effect of an extract of Withania somnifera root on estrogen receptor-positive mammary carcinomas. Anticancer Res. 2013, 33, 1519-1523.

118. Zhang, X.; Mukerji, R.; Samadi, A.K.; Cohen, M.S. Down-regulation of estrogen receptor-alpha and rearranged during transfection tyrosine kinase is associated with withaferin a-induced apoptosis in MCF-7 breast cancer cells. BMC Complement. Altern. Med. 2011, 11, 84. [CrossRef]

119. Sehrawat, A.; Samanta, S.K.; Hahm, E.R.; St Croix, C.; Watkins, S.; Singh, S.V. Withaferin A-mediated apoptosis in breast cancer cells is associated with alterations in mitochondrial dynamics. Mitochondrion 2019, 47, 282-293. [CrossRef]

120. Ghosh, K.; De, S.; Mukherjee, S.; Das, S.; Ghosh, A.N.; Sengupta, S.B. Withaferin A induced impaired autophagy and unfolded protein response in human breast cancer cell-lines MCF-7 and MDA-MB-231. Toxicol. In Vitro 2017, 44, 330-338. [CrossRef]

121. Szarc vel Szic, K.; Op de Beeck, K.; Ratman, D.; Wouters, A.; Beck, I.M.; Declerck, K.; Heyninck, K.; Fransen, E.; Bracke, M.; De Bosscher, K.; et al. Pharmacological levels of Withaferin A (Withania somnifera) trigger clinically relevant anticancer effects specific to triple negative breast cancer cells. PLoS ONE 2014, 9, e87850. [CrossRef] [PubMed]

122. Salve, J.; Pate, S.; Debnath, K.; Langade, D. Adaptogenic and Anxiolytic Effects of Ashwagandha Root Extract in Healthy Adults: A Double-blind, Randomized, Placebo-controlled Clinical Study. Cureus 2019, 11, e6466. [CrossRef] [PubMed]

123. Singh, N.; Bhalla, M.; de Jager, P.; Gilca, M. An overview on ashwagandha: A rasayana (rejuvenator) of ayurveda. Afr. J. Tradit. Complement. Altern. Med. 2011, 8, 208-213. [CrossRef] [PubMed]

124. Lopresti, A.L.; Smith, S.J.; Malvi, H.; Kodgule, R. An investigation into the stress-relieving and pharmacological actions of an ashwagandha (Withania somnifera) extract: A randomized, double-blind, placebo-controlled study. Medicine 2019, 98, e17186. [CrossRef] 
125. Olff, M.; Güzelcan, Y.; de Vries, G.J.; Assies, J.; Gersons, B.P. HPA- and HPT-axis alterations in chronic posttraumatic stress disorder. Psychoneuroendocrinology 2006, 31, 1220-1230. [CrossRef]

126. Vincent, M.; Yogiraj, K. A Descriptive Study of Alopecia Patterns and their Relation to Thyroid Dysfunction. Int. J. Trichol. 2013, 5, 57-60. [CrossRef]

127. Sharma, A.K.; Basu, I.; Singh, S. Efficacy and Safety of Ashwagandha Root Extract in Subclinical Hypothyroid Patients: A Double-Blind, Randomized Placebo-Controlled Trial. J. Altern. Complement. Med. 2018, 24, 243-248. [CrossRef]

128. van Beek, N.; Bodó, E.; Kromminga, A.; Gáspár, E.; Meyer, K.; Zmijewski, M.A.; Slominski, A.; Wenzel, B.E.; Paus, R. Thyroid hormones directly alter human hair follicle functions: Anagen prolongation and stimulation of both hair matrix keratinocyte proliferation and hair pigmentation. J. Clin. Endocrinol. Metab. 2008, 93, 4381-4388. [CrossRef]

129. Chandrasekhar, K.; Kapoor, J.; Anishetty, S. A prospective, randomized double-blind, placebo-controlled study of safety and efficacy of a high-concentration full-spectrum extract of ashwagandha root in reducing stress and anxiety in adults. Indian J. Psychol. Med. 2012, 34, 255-262. [CrossRef] [PubMed]

130. Sellami, R.; Masmoudi, J.; Ouali, U.; Mnif, L.; Amouri, M.; Turki, H.; Jaoua, A. The relationship between alopecia areata and alexithymia, anxiety and depression: A case-control study. Indian J. Dermatol. 2014, 59, 421. [CrossRef]

131. Phillips, T.G.; Slomiany, W.P.; Allison, R. Hair loss: Common causes and treatment. Am. Fam. Physician 2017, 96, 371-378. [PubMed]

132. Jiang, X.; Qu, Q.; Li, M.; Miao, S.; Li, X.; Cai, W. Horsetail mixture on rheumatoid arthritis and its regulation on TNF-alpha and IL-10. Pak. J. Pharm. Sci. 2014, 27, 2019-2023. [PubMed]

133. Park, E.Y.; Jeon, H. Antioxidant and Anti-inflammatory Activities of Equisetum hyemale. Nat. Prod. Sci. 2008, 14, 239-243.

134. Cetojević-Simin, D.D.; Canadanović-Brunet, J.M.; Bogdanović, G.M.; Djilas, S.M.; Cetković, G.S.; Tumbas, V.T.; Stojiljković, B.T. Antioxidative and antiproliferative activities of different horsetail (Equisetum arvense L.) extracts. J. Med. Food 2010, 13, 452-459.

135. Chaiyana, W.; Punyoyai, C.; Somwongin, S.; Leelapornpisid, P.; Ingkaninan, K.; Waranuch, N.; Srivilai, J.; Thitipramote, N.; Wisuitiprot, W.; Schuster, R.; et al. Inhibition of $5 \alpha$-Reductase, IL-6 Secretion, and Oxidation Process of Equisetum debile Roxb. ex Vaucher Extract as Functional Food and Nutraceuticals Ingredients. Nutrients 2017, 10, 9. [CrossRef]

136. Atalay, P.B.; Kuku, G.; Tuna, B.G. Effects of carbendazim and astaxanthin co-treatment on the proliferation of MCF-7 breast cancer cells. In Vitr. Cell. Dev. Biol. Anim. 2019, 55, 113-119. [CrossRef]

137. McCall, B.; McPartland, C.K.; Moore, R.; Frank-Kamenetskii, A.; Booth, B.W. Effects of Astaxanthin on the Proliferation and Migration of Breast Cancer Cells In Vitro. Antioxidants 2018, 7, 135. [CrossRef]

138. Naji, T.; Niazi, S.; Hamedani, P.S.K. The Cytotoxic Effects of Astaxanthin on Breast Cancer Cells. In Proceedings of the International Conference on BioMedical Sciences (ICBMS19), Istanbul, Turkey, 27-28 September 2019. Conference Book.

139. Karimian, A.; Hajizadeh Moghaddam, A.; Mir Mohammadrezaei, F. Effect of Astaxanthin on cell viability in T-47D and MDA-MB-231 Breast Cancer Cell Lines. Multidiscip. Cancer Investig. 2017, 2017, 1. [CrossRef]

140. Zhang, L.; Wang, H. Multiple mechanisms of anti-cancer effects exerted by astaxanthin. Mar. Drugs 2015, 13, 4310-4330. [CrossRef]

141. Tang, Y.; Luo, B.; Deng, Z.; Wang, B.; Liu, F.; Li, J.; Shi, W.; Xie, H.; Hu, X.; Li, J. Mitochondrial aerobic respiration is activated during hair follicle stem cell differentiation, and its dysfunction retards hair regeneration. PeerJ 2016, 4, e1821. [CrossRef]

142. Catarino, M.D.; Silva, A.M.S.; Cardoso, S.M. Phycochemical Constituents and Biological Activities of Fucus spp. Mar. Drugs 2018, 16, 249. [CrossRef] [PubMed]

143. Moussavou, G.; Kwak, D.H.; Obiang-Obonou, B.W.; Maranguy, C.A.; Dinzouna-Boutamba, S.D.; Lee, D.H.; Pissibanganga, O.G.; Ko, K.; Seo, J.I.; Choo, Y.K. Anticancer effects of different seaweeds on human colon and breast cancers. Mar. Drugs 2014, 12, 4898-4911. [CrossRef] [PubMed]

144. Vaikundamoorthy, R.; Krishnamoorthy, V.; Vilwanathan, R.; Rajendran, R. Structural characterization and anticancer activity (MCF7 and MDA-MB-231) of polysaccharides fractionated from brown seaweed Sargassum Wightii. Int. J. Biol. Macromol. 2018, 111, 1229-1237. [CrossRef] [PubMed] 
145. Vetvicka, V.; Vetvickova, J. Fucoidans Stimulate Immune Reaction and Suppress Cancer Growth. Anticancer Res. 2017, 37, 6041-6046.

146. Malyarenko, O.S.; Zdobnova, E.V.; Silchenko, A.S.; Kusaykin, M.I.; Ermakova, S.P. Radiosensitizing effect of the fucoidan from brown alga Fucus evanescens and its derivative in human cancer cells. Carbohydr. Polym. 2019, 205, 465-471. [CrossRef]

147. Pawar, V.K.; Singh, Y.; Sharma, K.; Shrivastav, A.; Sharma, A.; Singh, A.; Meher, J.G.; Singh, P.; Raval, K.; Kumar, A.; et al. Improved chemotherapy against breast cancer through immunotherapeutic activity of fucoidan decorated electrostatically assembled nanoparticles bearing doxorubicin. Int. J. Biol. Macromol. 2019, 122, 1100-1114. [CrossRef]

148. Abudabbus, A.; Badmus, J.A.; Shalaweh, S.; Bauer, R.; Hiss, D. Effects of Fucoidan and Chemotherapeutic Agent Combinations on Malignant and Non-malignant Breast Cell Lines. Curr. Pharm. Biotechnol. 2017, 18, 748-757. [CrossRef]

149. Tocaciu, S.; Oliver, L.J.; Lowenthal, R.M.; Peterson, G.M.; Patel, R.; Shastri, M.; McGuinness, G.; Olesen, I.; Fitton, J.H. The Effect of Undaria pinnatifida Fucoidan on the Pharmacokinetics of Letrozole and Tamoxifen in Patients with Breast Cancer. Integr. Cancer Ther. 2018, 17, 99-105. [CrossRef]

150. Kang, J.I.; Kim, M.K.; Lee, J.H.; Jeon, Y.J.; Hwang, E.K.; Koh, Y.S.; Hyun, J.W.; Kwon, S.Y.; Yoo, E.S.; Kang, H.K. Undariopsis peterseniana Promotes Hair Growth by the Activation of Wnt/ $\beta$-Catenin and ERK Pathways. Mar. Drugs 2017, 15, 130. [CrossRef]

151. Shin, H.; Cho, A.R.; Kim, D.Y.; Munkhbayer, S.; Choi, S.J.; Jang, S.; Kim, S.H.; Shin, H.C.; Kwon, O. Enhancement of Human Hair Growth Using Ecklonia cava Polyphenols. Ann. Dermatol. 2016, 28, 15-21. [CrossRef]

152. Kang, J.I.; Kim, S.C.; Kim, M.K.; Boo, H.J.; Jeon, Y.J.; Koh, Y.S.; Yoo, E.S.; Kang, S.M.; Kang, H.K. Effect of Dieckol, a component of Ecklonia cava, on the promotion of hair growth. Int. J. Mol. Sci. 2012, 13, 6407-6423. [CrossRef] [PubMed]

153. Fukuta, K.; Nakamura, T. Induction of hepatocyte growth factor by fucoidan and fucoidan-derived oligosaccharides. J. Pharm. Pharmacol. 2008, 60, 499-503. [CrossRef] [PubMed]

154. Jindo, T.; Tsuboi, R.; Takamori, K.; Ogawa, H. Local injection of hepatocyte growth factor/scatter factor (HGF/SF) alters cyclic growth of murine hair follicles. J. Investig. Dermatol. 1998, 110, 338-342. [CrossRef] [PubMed]

155. Seok, J.; Kim, T.S.; Kwon, H.J.; Lee, S.P.; Kang, M.H.; Kim, B.J.; Kim, M.N. Efficacy of Cistanche Tubulosa and Laminaria Japonica Extracts (MK-R7) Supplement in Preventing Patterned Hair Loss and Promoting Scalp Health. Clin. Nutr. Res. 2015, 4, 124-131. [CrossRef] [PubMed]

156. Park, K.S.; Park, D.H. Comparison of Saccharina japonica-Undaria pinnatifida Mixture and Minoxidil on Hair Growth Promoting Effect in Mice. Arch. Plast. Surg. 2016, 43, 498-505. [CrossRef]

157. D'Angelo, S.; Martino, E.; Cacciapuoti, G. Effects of Annurca Apple (Malus pumila cv Annurca) Polyphenols on Breast Cancer Cells. Curr. Nutr. Food Sci. 2019, 15, 745-751. [CrossRef]

158. Piccolo, M.; Ferraro, M.G.; Maione, F.; Maisto, M.; Stornaiuolo, M.; Tenore, G.C.; Santamaria, R.; Irace, C.; Novellino, E. Induction of Hair Keratins Expression by an Annurca Apple-Based Nutraceutical Formulation in Human Follicular Cells. Nutrients 2019, 11, 3041. [CrossRef]

159. Luo, Z.; Zeng, H.; Ye, Y.; Liu, L.; Li, S.; Zhang, J.; Luo, R. Safflower polysaccharide inhibits the proliferation and metastasis of MCF-7 breast cancer cell. Mol. Med. Rep. 2015, 11, 4611-4616. [CrossRef]

160. Junlatat, J.; Sripanidkulchai, B. Hair growth-promoting effect of Carthamus tinctorius floret extract. Phytother Res. 2014, 28, 1030-1036. [CrossRef]

161. Cai, J.; Wen, R.; Li, W.; Wang, X.; Tian, H.; Yi, S.; Zhang, L.; Li, X.; Jiang, C.; Li, H. Oil body bound oleosin-rhFGF9 fusion protein expressed in safflower (Carthamus tinctorius L.) stimulates hair growth and wound healing in mice. BMC Biotechnol. 2018, 18, 51. [CrossRef]

162. Thoennissen, N.H.; O’Kelly, J.; Lu, D.; Iwanski, G.B.; La, D.T.; Abbassi, S.; Leiter, A.; Karlan, B.; Mehta, R.; Koeffler, H.P. Capsaicin causes cell-cycle arrest and apoptosis in ER-positive and-negative breast cancer cells by modulating the EGFR/HER-2 pathway. Oncogene 2010, 29, 285-296. [CrossRef] [PubMed]

163. Rastegar, H.; Ahmadi Ashtiani, H.; Aghaei, M.; Ehsani, A.; Barikbin, B. Combination of herbal extracts and platelet-rich plasma induced dermal papilla cell proliferation: Involvement of ERK and Akt pathways. J. Cosmet. Dermatol. 2013, 12, 116-122. [CrossRef] [PubMed] 
164. Paus, R.; Heinzelmann, T.; Schultz, K.D.; Furkert, J.; Fechner, K.; Czarnetzki, B.M. Hair growth induction by substance P. Lab. Investig. 1994, 71, 134-140. [PubMed]

165. Bassino, E.; Gasparri, F.; Munaron, L. Protective Role of Nutritional Plants Containing Flavonoids in Hair Follicle Disruption: A Review. Int. J. Mol. Sci. 2020, 21, 523. [CrossRef] [PubMed]

166. Kim, S.J.; Kim, A.K. Anti-breast cancer activity of Fine Black ginseng (Panax ginseng Meyer) and ginsenoside Rg5. J. Ginseng. Res. 2015, 39, 125-134. [CrossRef] [PubMed]

167. Kang, J.H.; Song, K.H.; Woo, J.K.; Park, M.H.; Rhee, M.H.; Choi, C.; Oh, S.H. Ginsenoside Rp1 from Panax ginseng Exhibits Anti-cancer Activity by Down-regulation of the IGF-1R/Akt Pathway in Breast Cancer Cells. Plant Foods Hum. Nutr. 2011, 66, 298-305. [CrossRef]

168. Keum, D.I.; Pi, L.Q.; Hwang, S.T.; Lee, W.S. Protective effect of Korean Red Ginseng against chemotherapeutic drug-induced premature catagen development assessed with human hair follicle organ culture model. J. Ginseng. Res. 2016, 40, 169-175. [CrossRef]

169. Lee, Y.; Kim, S.N.; Hong, Y.D.; Park, B.C.; Na, Y. Panax ginseng extract antagonizes the effect of DKK-1-induced catagen-like changes of hair follicles. Int. J. Mol. Med. 2017, 40, 1194-1200. [CrossRef]

Publisher's Note: MDPI stays neutral with regard to jurisdictional claims in published maps and institutional affiliations.

(C) 2020 by the authors. Licensee MDPI, Basel, Switzerland. This article is an open access article distributed under the terms and conditions of the Creative Commons Attribution (CC BY) license (http://creativecommons.org/licenses/by/4.0/). 